経 営 史 学

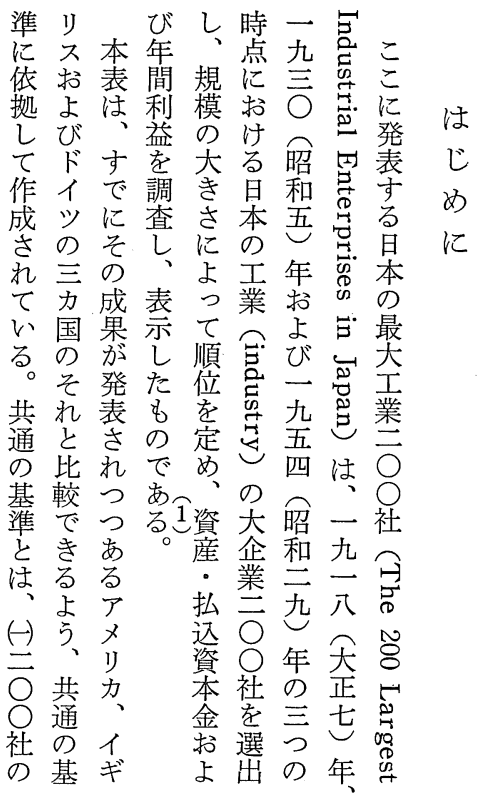

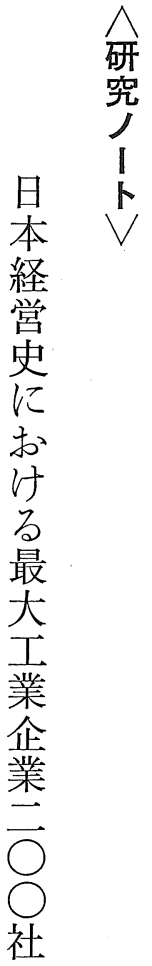

題早に尔し@選なよて最 時のい機本包、し一な工

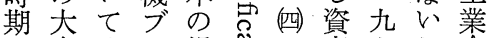

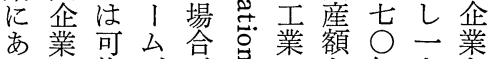
たは能が、年九を る戦加起 $(G)$ 品範し前年選 の後つっの田囲、後、出 での適た時导やよを一立、 一建で年に妾類正る亥規

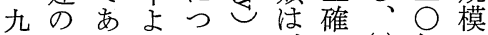
五途るりいに、加年に 四上㤎もてょアつ選、よ 年に望はるメ網出一り にあ一ま、こリ羅抒九順 する九し一と的よ四位 らう四、九、力なび分 しえ八し二のの数順年 た、打四 S 学位なる、 ま娠品びよ年点 $\mathrm{I}$ が た再に二こあたら準四時 $\Leftrightarrow$ 評つ九のる。怘れ点 の価い年。气る売年は 選のて 出問は年方だ丟を高お九 
ひこ筆社でもさ告は、る基

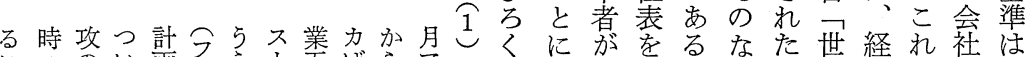

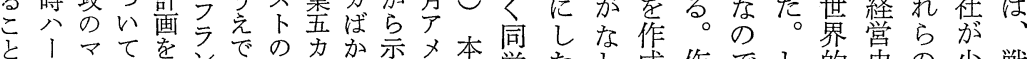
之バの断主作国り唆り表学たし成作でし的史の少戦

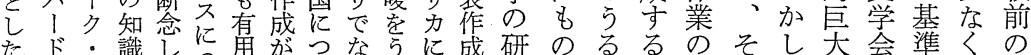
たド・識しに用がつならに成研のるるのそし大会準くの の学フをたいで、いく拉究で努こ性の右企第にな、 で学ルも茸ては当でたいそ者あ力と格後の業一もい本

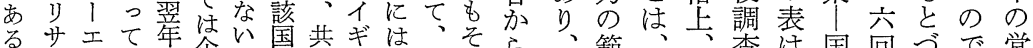

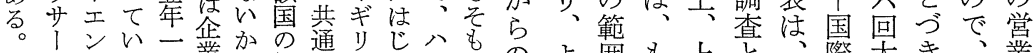

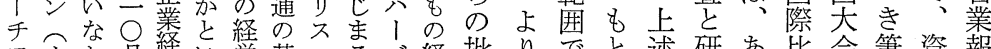
フ为加経い嫦・る心経批りでと述研 あ比会筆資報

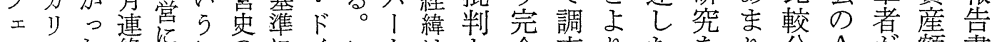
口フた絡にこのにイこト法と全查りたをり分 $\mathrm{A}$ が額書

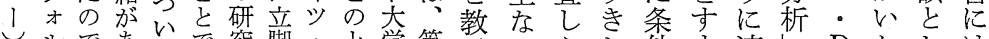

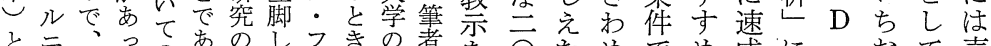

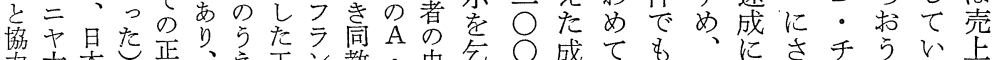

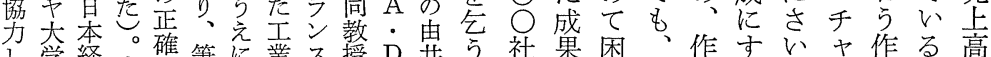

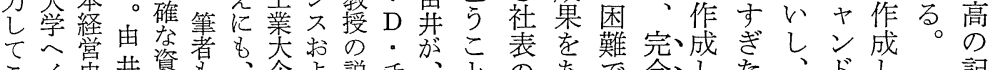

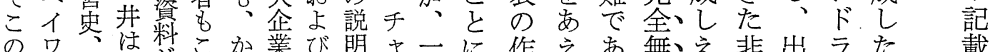
のワ、注料こ業び明ヤ一に作えあ無え非出ラた載

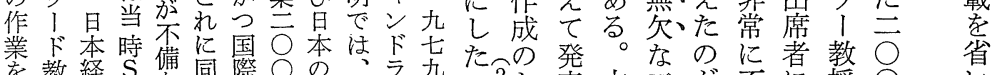

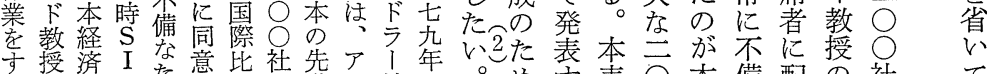

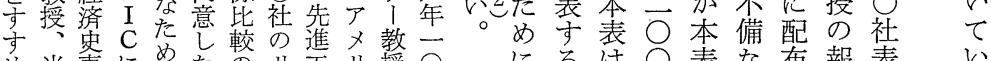

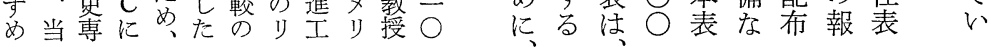

にか金資多称らここず

そら、本く資れと第て対本

く、未金の本てで一説象表

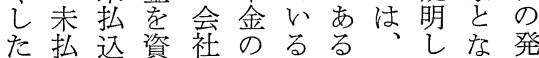

た払込資社のるる。既て方登

謷資金金営分亏た述お主市

を本考業のにだのか○趣

資金を株報一次とな 旨

産の計金告払公戦おけ社と

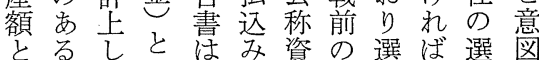

とるしと岁殞の選ば選図

る合いて貸多金本と占点上

こはる揭借々金の順な序述

とそ。げ、効の払株位い列の

とのそつ照企込式の。おと

し金こ資表業資会基文お

た額で産の怔本社準びり列 学本痤設金にを、範での

さ控表部負立の㧤。囲あ基

ら除で嘖さ区い資にる準

にしはに方机別て産、かが、

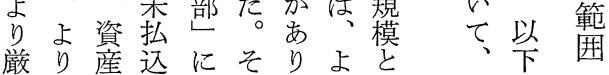

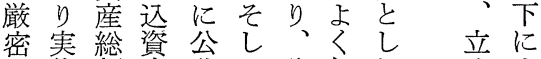

に体額本称て公知た六ま

ないこ日諸季中額て $\overparen{2}$ い。れ本表号村では ししら経テ济素た産ら 本しい統夕占主業乙 工表算ず計、び百要政た 業の者机紊べ松本企策過 作はも献 1 田株業史去 成こ約七不芳式順研に にれーン郎会位究お あら○名明社の所け た先○1治大二史口る 口駆社刊虫昔○的 て的の期博 ○変が本 \&研 リ既处美年遷国の 十究不刊品美早 分の下羊昭野別企企 参労で冊和島刑同業業 䓔苦あ昭前島冊同研のの に索り昭期垶中研形り さ評、和气兄究成 せ価脱吾橋格枀所登卢

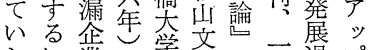
たに業な経子丸九過 プ 㤁少唯斎企七七!成 たさな吕研業分窂総果 でなる。所務秋、鉒し 


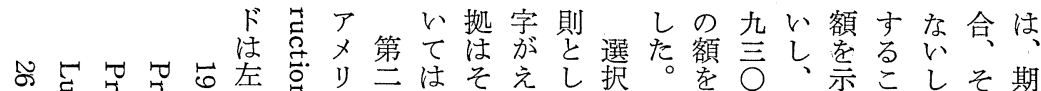

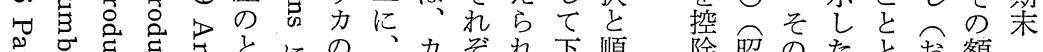

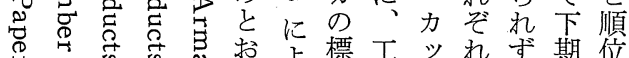

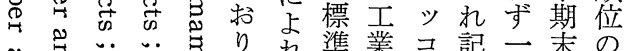

苞芯

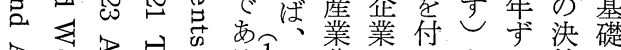

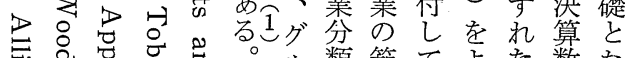

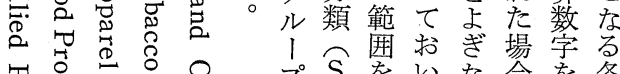

ஏ

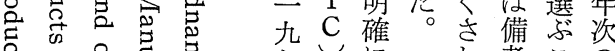

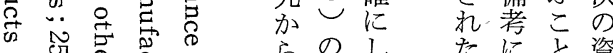

心. 心

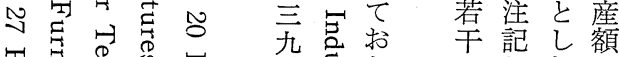

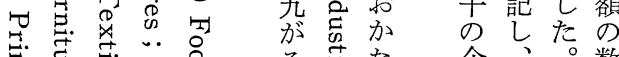

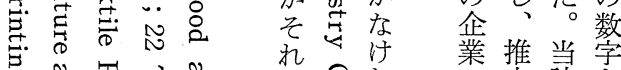

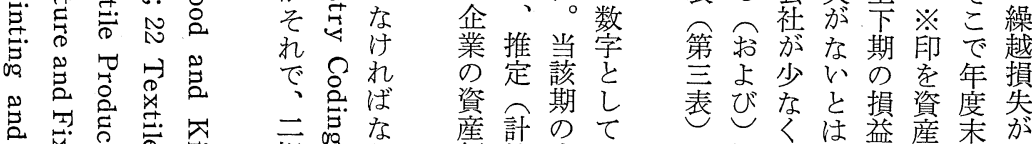

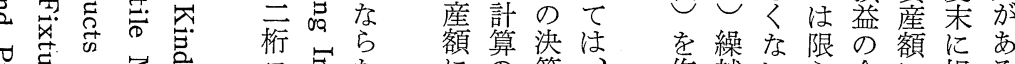

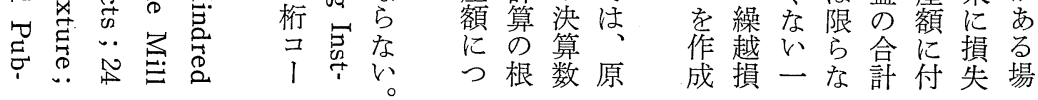

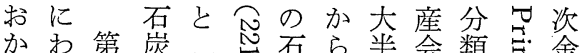

かわ第炭包志石方半会類哥金注

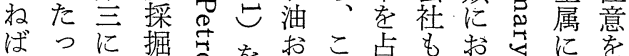

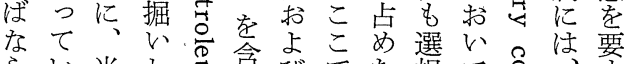

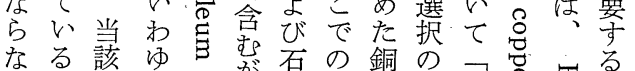

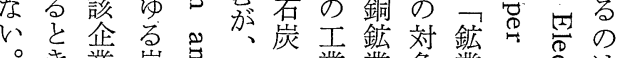

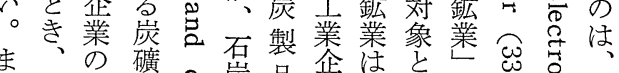

ま乞活礦崖品業は、と岕

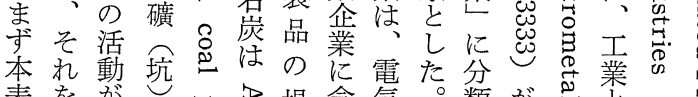

表をが嵒場含気。類が导美

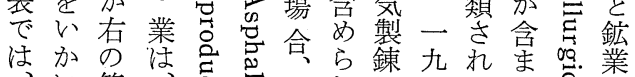

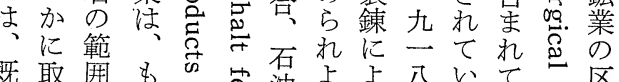

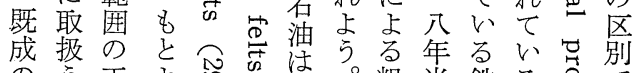

成扱 の

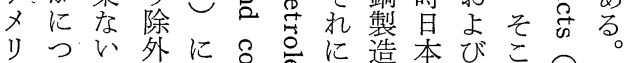

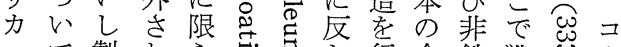

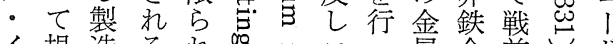

イ規造るれ范コつ属金前

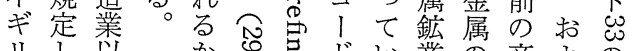

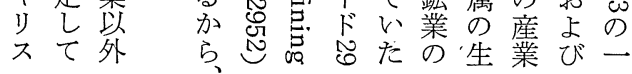

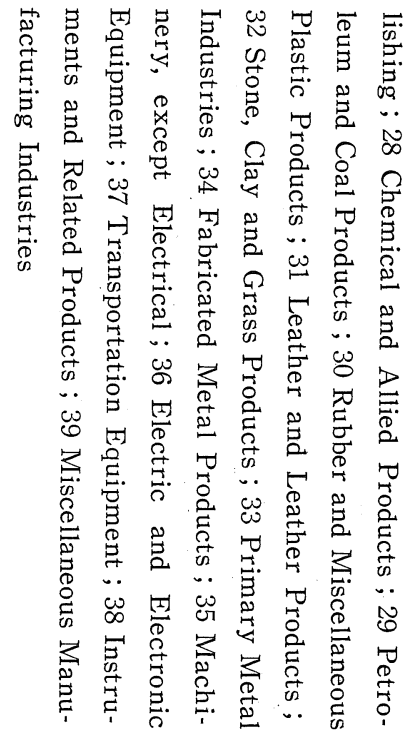


とむ持二前策売なアやかを付上なををな しをさ株 ○期決上いメ類右らち記高さの场 たえて会○の定高しリ似のでろし筑らで例工てえ合 こなこ社社日の咕支力の方あんた総に選え業選るに と、5は表本主計配や企式る、額順択ば部択かな のとし対ので体上しイ業で。順この位さ一門し、ら たはて象意々をさてギ形選位れ四五机九のたこっ

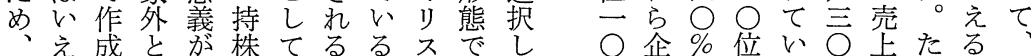
筆えしし著会持ことのあ順つ業未以る年高だと工 者基たたし社株とき場っ位位は満内流の恕し判業 は準最。くを会驾合たら方芯の゙日四順断部

そ嫦圭失選社々そ択のりの服け部た企業も卡魯 位さ門 そ営工わ択のりの持部た れ業業枋方普さ株時た

に報企るるるが通い会計め

と告業こと選で持社店

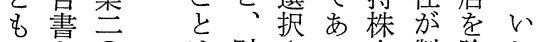

な考 $\vec{\bigcirc}$ 財さっ会製除わ

う心○明閥れた社造いゆ 実１社白直てょ側企てる

体不表で系いうに業表持

的とに亦るで被を示株

なしつる業。あ支完さ会

規たい资しる配全れ社

模資て、气除加る企になる。

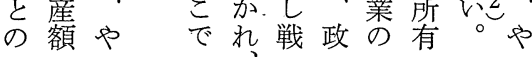

の産一大

その○企

絶\%業

を対以で

上額上は

わ一企工

可 美業

能 $\bigcirc$ 別関

性位表成

あ内乞の

るはて売
漁 \% 五 れ

業以 $\bigcirc$ る売

は上位企上

売の以業高

上企丙汃

高業の、営

の孝原業

四亦位則収

○含大と入 $\%$ 企し 全 がる業て体 加こに工の 工とつ業五 食とい企○ 品して業\%

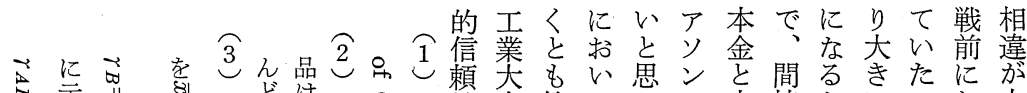

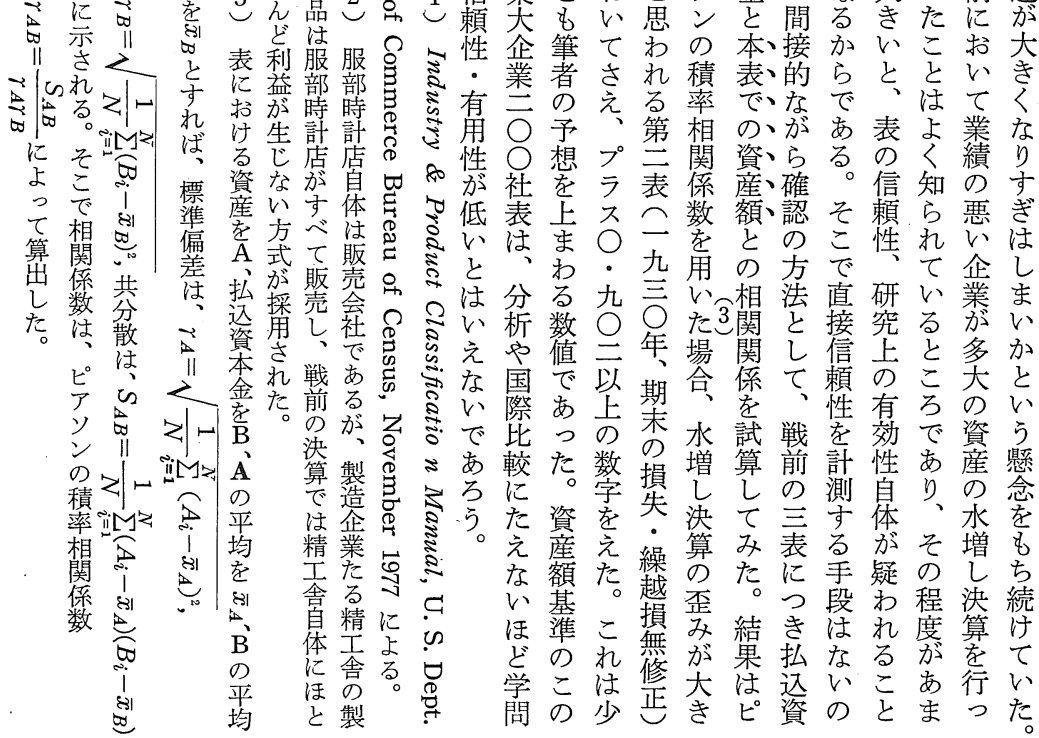


経営史学

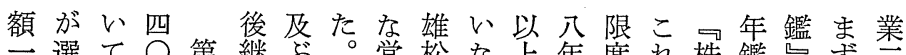

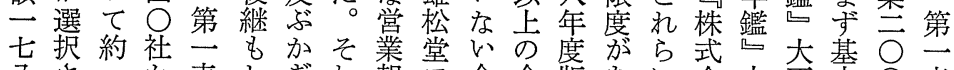

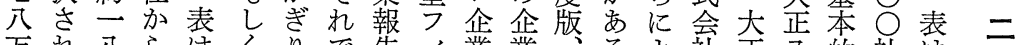
万茨ら注くりで告イ業業方よ社正分的社注 円る○、淔も書ル情同こっ年分年なで、

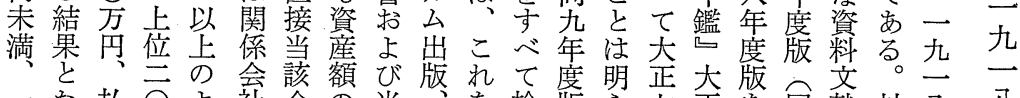
一な払

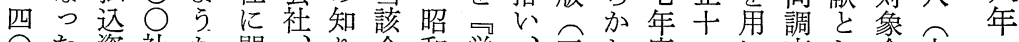
た資社な問り会和嫦、㺯な度二、租し企大の 万。本を手いなえ社四業前業のの年、部て業正最

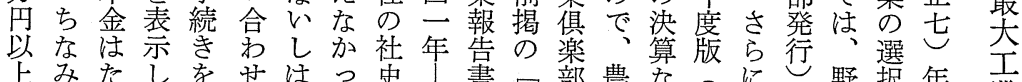
のにまたへる消たに五雃株登商い第参お村は度業 会順たもてこ滅諸よ亲成武行務し䓔よ商次年企 社位まのりと企会っ年年し省資回とび店の期業

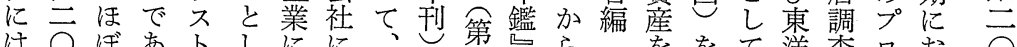

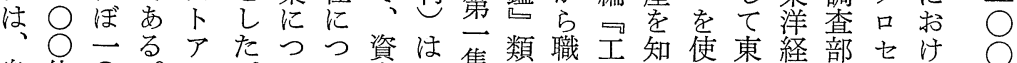
泉位○資プ

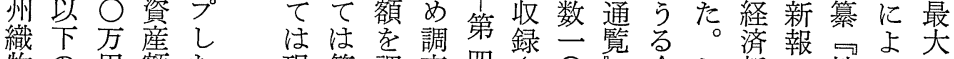
物の网額た現筆調查四さ○䙷企し新株っ品

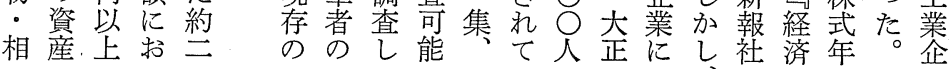

し社事業第たは記か住知線五なの・佐球島模

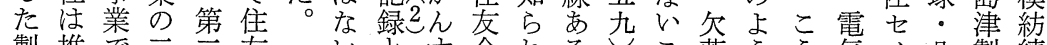
製推で二三友二いと合れるしこ落うう気丈凹製績 采計も、に総九け一る資ていのととなし製ン版㤰・ 企值ま三、本一社九数会いはほをし明て鉄卜留所三 業でま社同后八ど二学社る肥か指てら本・・刷・重 はリ少族が年も八沙と料、摘は加表長朝・旭圭 スな欠企欠の誤年い設おなこしいな瀬鮮東電メ

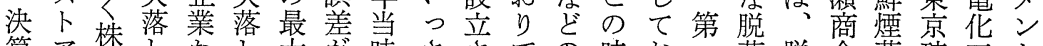
算ア式しなし大㭠ささでの時お落脱会草硫立卜

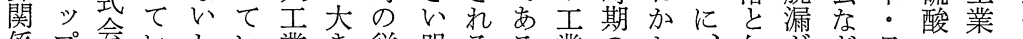

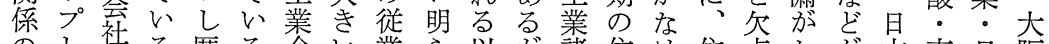
のし社る匿る企心業ら以势諸住住点なが本南日服 資た改こ名こ業危員加前、部友れ友をいあ電海東采

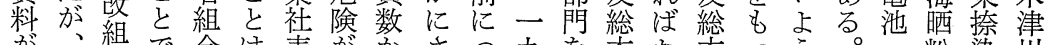
汃、組で合は表加吕さつ,九を本な本っう。粉染川

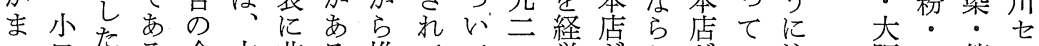
つ质る企本非る推てて二棠がながい注阪日第义 た組倉同業表鉄の計いは学銅いリる意。莫本一ン

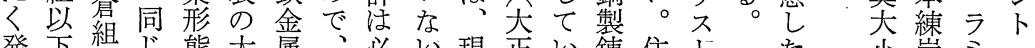
発下組し態大属、必現正い鍊住下た䈐ミ!

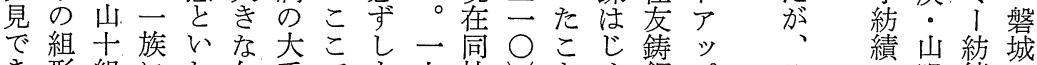

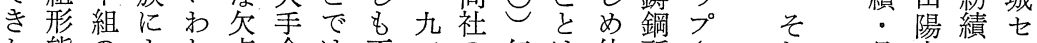
な態のよれ点企は不三の年は伸所さ桠皮・メ

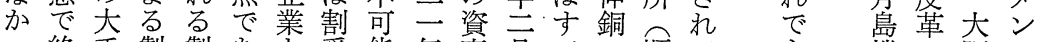

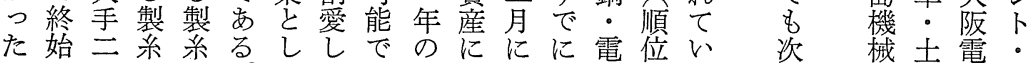


第18巻 第 1 号

第 1 表 最大工業企業200社; 1918(大正 7)年 （単位: 1,000円)

\begin{tabular}{|c|c|c|c|c|c|c|}
\hline 順位 & 社 & & 資 産 & 払込資本金 & 利 益 & 備 \\
\hline 1 & 川 崎 造 船 & & 140,347 & 45,000 & 29,368 & \\
\hline 2 & 久 原 鉱 & 業 & 103,610 & 41,250 & 17,116 & \\
\hline 3 & 三 菱 造 & 船 & 89,327 & 30,000 & 13,116 & \\
\hline 4 & 鐘 淵 紡 & 績 & 69,936 & 15,786 & 19,089 & \\
\hline 5 & 洋 & 績 & 61,705 & 18,550 & 18,774 & \\
\hline 6 & 大 日 本 紡 & 績 & 59,209 & 22,580 & 17,365 & \\
\hline 7 & 湾＼cjkstart製 & 糖 & 55,930 & 20,835 & 6,841 & \\
\hline 8 & 三 菱 製 & 鉄 & 46,942 & 30,000 & - & \\
\hline 9 & 富士瓦 斯 紡 & 績. & 40,059 & 13,000 & 10,893 & \\
\hline 10 & 日＼cjkstart本＼cjkstart鋼 & 管 & 39,374 & 9,400 & 5,945 & \\
\hline 11 & 大 日 本 製 & 糖 & 38,219 & 18,000 & 5,231 & \\
\hline 12 & 河＼cjkstart鉱 & 業 & 36,938 & 20,000 & 4,198 & \\
\hline 13 & 本石 & 油 & 36,655 & 25,000 & 8,138 & \\
\hline 14 & 王子＼cjkstart製 & 紙 & 35,928 & 15,250 & 6,260 & \\
\hline 15 & 日 本 製 鋼 & 所 & 35,863 & 15,000 & 4,050 & \\
\hline 16 & 塩水港製 糖 拓 & 殖 & 35,782 & 11,250 & 5,287 & \\
\hline 17 & 日本 毛 & 織 & 34,722 & 10,000 & 4,975 & \\
\hline 18 & 製 & 紙 & 32,826 & 17,425 & 6,692 & \\
\hline 19 & 浦 賀 船 & 渠 & 32,708 & 10,000 & 3,747 & \\
\hline 20 & 宝＼cjkstart田＼cjkstart石 & 油 & 32,153 & 16,250 & 6,198 & \\
\hline 21 & 大阪 鉄 工 & 所 & 29,932 & 10,500 & 9,104 & \\
\hline 22 & 播 磨 造 船 & 所 & $(29,824)$ & 10,000 & & 1920年12月資産 46,600 千円 \\
\hline 23 & 田 中 鉱 & 山 & 28,774 & 20,000 & 412 & 1919年上期 \\
\hline 24 & 明 治 製 & 糖 & 28,337 & 8,925 & 3,216 & \\
\hline 25 & 外 & 綿 & 27,005 & 3,750 & 3,530 & \\
\hline 26 & 神 戸，製 鋼 & 所 & 26,143 & 10,000 & 4,895 & \\
\hline 27 & 東＼cjkstart京＼cjkstart製 & 綱 & 25,639 & 7,000 & 5,827 & \\
\hline 28 & 国製 & 糖 & 25,476 & 9,375 & 3,867 & \\
\hline 29 & 大 阪 合 同 紡 & 績 & 25,382 & 8,738 & 11,393 & \\
\hline 30 & 浅 野 セ メ ン & ト & 25,363 & 9,135 & 2,809 & \\
\hline 31 & 片＼cjkstart倉 & 組 & $(24,794)$ & & & 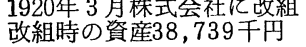 \\
\hline 32 & 芝 浦 製 作 & 所 & 24,189 & 5,000 & 5,912 & \\
\hline 33 & 東＼cjkstart洋＼cjkstart製 & 糖 & 23,896 & 10,110 & 8,268 & \\
\hline 34 & 東京石川島造船 & 所 & 21,318 & 2,868 & 5,051 & \\
\hline 35 & 東＼cjkstart京＼cjkstart毛 & 織 & 21,060 & 14,000 & 3,615 & \\
\hline 36 & 大日本人造肥 & 料 & 20,423 & 10,375 & 2,148 & \\
\hline 37 & 横＼cjkstart浜＼cjkstart船 & 渠 & 20,274 & 5,315 & 4,022 & \\
\hline 38 & 国 & 麻 & 19,540 & 8,000 & 4,825 & \\
\hline 39 & 台＼cjkstart南＼cjkstart製 & 糖 & 17,537 & 8,985 & 1,098 & \\
\hline 40 & 大日 本 麦 & 酒 & 17,194 & 8,800 & 4,031 & \\
\hline
\end{tabular}




\begin{tabular}{|c|c|c|c|c|c|}
\hline 41 & 日本窒素肥 料 & 15,333 & 7,600 & 3,026 & \\
\hline 42 & $\begin{array}{lll}\text { 藤 田 鉱 業 }\end{array}$ & $(15,300)$ & 15,000 & & (資産) は，払込資本金に \\
\hline 43 & 北 海 道 製 鉄 & $(15,000)$ & 15,000 & & \\
\hline 44 & 東京瓦斯電気工業 & 14,901 & 4,750 & 977 & \multirow{5}{*}{$\begin{array}{l}\text { 下期末損失差引資産 } \\
13,015 \text { 干円(修正順位 49) }\end{array}$} \\
\hline 45 & 新 高 製 糖 & 14,581 & 5,000 & 2,261 & \\
\hline 46 & 大阪亜、鉛鉱業 & $※ 13,796$ & 5,000 & $-2,234$ & \\
\hline 47 & 倉 敷 紡 績 & 13,679 & 4,120 & 4,636 & \\
\hline 48 & 毛 斯 倫 紡 織 & 13,047 & 7,500 & 2,419 & \\
\hline 49 & 浅野小倉製 鋼所 & 12,850 & 6,000 & 0 & \multirow[t]{17}{*}{ 1919年下期 } \\
\hline 50 & 川北電 気 企業 & 12,668 & 9,000 & 815 & \\
\hline 51 & 福 島 紡 績 & 12,494 & 4,000 & 3,553 & \\
\hline 52 & 東京モスリン紡織 & 12,123 & 5,500 & 1,924 & \\
\hline 53 & 大 日 本塩業 & 12,070 & 3,803 & 264 & \\
\hline 54 & 岸 和 田 紡 & 11,602 & 3,025 & 4,321 & \\
\hline 55 & 東＼cjkstart亜＼cjkstart煙 & 11,579 & 2,500 & 649 & \\
\hline 56 & 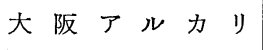 & 11,328 & 3,413 & 518 & \\
\hline 57 & 富士 製 & 11,176 & 5,884 & 1,036 & \\
\hline 58 & 阪 & 10,942 & 5,088 & 1,723 & \\
\hline 59 & 洋 & 10,855 & 10,317 & 264 & \\
\hline 60 & $太$ & 10,064 & 2,000 & 1,888 & \\
\hline 61 & 東＼cjkstart京 & 9,486 & 6,000 & 1,843 & \\
\hline 62 & 製 & 9,348 & 5,000 & 1,106 & \\
\hline 63 & 日＼cjkstart清＼cjkstart紡 & 9,347 & 4,000 & 3,473 & \\
\hline 64 & 住 友 鋳 鋼 & 9,185 & 4,500 & 1,352 & \\
\hline 65 & 旭硝 & 9,069 & 3,050 & 1,539 & \\
\hline 66 & 豊＼cjkstart田＼cjkstart紡 & 9,058 & 5,000 & 209 & \multirow[t]{5}{*}{ 1919年上期 } \\
\hline 67 & ラ サ，島 燐 & 9,020 & 6,000 & 1,390 & \\
\hline 68 & 秋田木材 & 8,729 & 2,750 & 1,380 & \\
\hline 69 & 電 気 化 学工業 & 8,323 & 5,000 & 2,757 & \\
\hline 70 & 関 東 酸 曹 & 8,169 & 3,250 & 1,316 & \\
\hline 71 & 田 造 船 & $(8,130)$ & 2,000 & & \multirow[t]{6}{*}{ 1920年下期資産 12,717 千円 } \\
\hline 72 & 車＼cjkstart製 & 8,095 & 2,212 & 624 & \\
\hline 73 & 大阪 造 船 & 7,978 & 2,375 & 1,777 & \\
\hline 74 & 日本＼cjkstart製 & 7,664 & 1,913 & 974 & \\
\hline 75 & 日本＼cjkstart製 & 7,543 & 3,500 & 2,299 & \\
\hline 76 & 上毛モスリ & 7,435 & 2,800 & 789 & \\
\hline 77 & 日本 製 布 & 7,260 & 2,250 & 616 & \multirow{4}{*}{$\begin{array}{l}\text { 1918年 } 7 \text { 月設音, } 1920 \text { 年 } \\
\text { 大同電気製鋼所 }\end{array}$} \\
\hline 78 & 木曽電 気 製 鉄 & 7,233 & 4,250 & 130 & \\
\hline 79 & 小野田セメント製造 & 7,063 & 2,700 & 746 & \\
\hline 80 & 日＼cjkstart本＼cjkstart電 & 7,010 & 2,500 & 1,400 & \\
\hline 81 & 野 田 罟 油 & $(7,000)$ & 7,000 & 0 & \multirow[t]{2}{*}{ 1917年12月設立 } \\
\hline 82 & 日本舎密製 造 & 6,979 & 2,600 & 1,482 & \\
\hline
\end{tabular}


第18巻 第 1 号

\begin{tabular}{|c|c|c|c|c|c|c|}
\hline 83 & $\equiv$ & 共 & 6,968 & 3,125 & 589 & \multirow{42}{*}{ 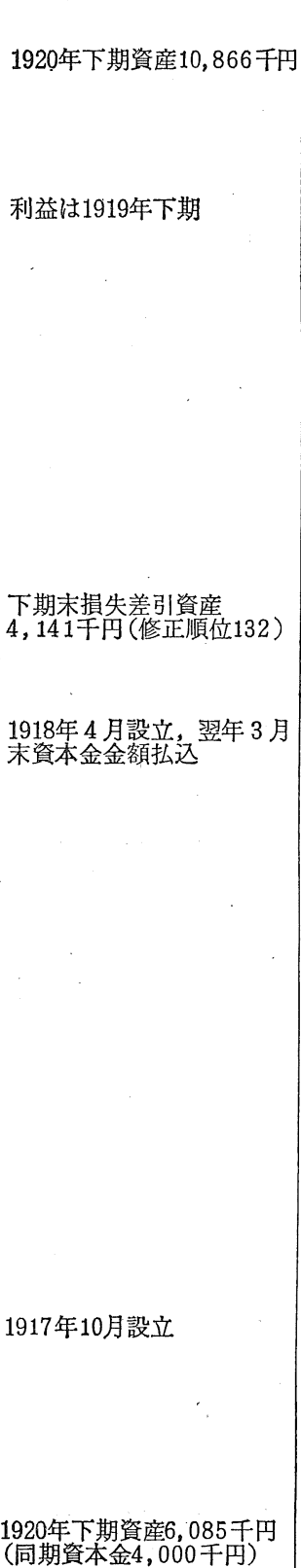 } \\
\hline 84 & 服 部 商 & 店 & $(6,950)$ & 4,000 & & \\
\hline 85 & 日本グリセリ & ン & 6,870 & 2,750 & 613 & \\
\hline 86 & 和 歌 山 紡 & 織 & 6,868 & 2,600 & 3,580 & \\
\hline 87 & 東＼cjkstart京＼cjkstart鋼 & 材 & 6,813 & 2,000 & 1,051 & \\
\hline 88 & 横 浜 電 線 製 & 造 & 6,703 & 1,875 & 495 & \\
\hline 89 & 日魯 漁 音 & 業 & 6,672 & 3,000 & 425 & \\
\hline 90 & 麒＼cjkstart麟＼cjkstart麦 & 酒 & 6,652 & 3,750 & 492 & \\
\hline 91 & 日 本 染 料 製 & 造 & 6,619 & 6,400 & 104 & \\
\hline 92 & 東 洋 モ ス リ & ン & 6,599 & 3,420 & 1,699 & \\
\hline 93 & 日＼cjkstart清＼cjkstart製 & 粉 & 6,567 & 2,275 & 902 & \\
\hline 94 & 日＼cjkstart華＼cjkstart紡 & 績 & 6,509 & 4,000 & 316 & \\
\hline 95 & 大阪 電 気 分 & 銅 & 6,413 & 3,750 & 1,115 & \\
\hline 96 & 日 出 紡 品 & 織 & 6,398 & 2,700 & 617 & \\
\hline 97 & 浅 野 造 & 船 & 6,250 & 3,750 & & \\
\hline 98 & 東京キャリコ製綡 & & 6,100 & 2,750 & 1,040 & \\
\hline 99 & 日本兵器製 & 造 & $※ 6,065$ & 2,375 & $-2,355$ & \\
\hline 100 & 横＼cjkstart浜＼cjkstart魚 & 油. & 6,040 & 2,800 & 890 & \\
\hline 101 & 本 & 革 & 6,012 & 2,500 & 952 & \\
\hline 102 & 野＼cjkstart製 & 鉄 & $(6,000)$ & 6,000 & - & \\
\hline 103 & 大 島 製 鋼 & 所 & 5,918 & 2,400 & 449 & \\
\hline 104 & 奥 村 電 機 商 & 会 & 5,832 & 3,500 & 852 & \\
\hline 105 & 日 清製 油 製 & 造 & 5,758 & 3,000 & 458 & \\
\hline 106 & 阪＼cjkstart製 & 鉄 & 5,715 & 2,328 & 1,006 & \\
\hline 107 & 満 州 製 & 糖 & 5,703 & 3,500 & 311 & \\
\hline 108 & 是＼cjkstart製 & 系 & 5,698 & 1,721 & 567 & \\
\hline 109 & 麦 & 酒 & 5,548 & 4,000 & 324 & \\
\hline 110 & 㤢 & 紙 & 5,545 & 1,750 & 701 & \\
\hline 111 & 天＼cjkstart満＼cjkstart織 & 物 & 5,451 & 2,750 & 1,004 & \\
\hline 112 & 日 本ペイン & r & 5,426 & $2 ; 375$ & 1,376 & \\
\hline 113 & 日本化学工 & 業 & 5,262 & 4,060 & 1,055 & \\
\hline 114 & 安＼cjkstart田＼cjkstart商 & 事 & 5,189 & 1,125 & 362 & \\
\hline 115 & 江＼cjkstart帆 & 布 & 5,048 & 600 & 610 & \\
\hline 116 & 川，白 棟 & 瓦 & 5,045 & 2,474 & 681 & \\
\hline 117 & 洋＼cjkstart製 & 紙 & 5,038 & 2,450 & 1,494 & \\
\hline 118 & 服 部 時 計 & 店 & $(5,000)$ & 5,000 & & \\
\hline 119 & 館＼cjkstart船 & 渠 & 4,979 & 2,000 & 1,536 & \\
\hline 120 & 洋 & 水 & 4,586 & 2,695 & 48 & \\
\hline 121 & 大＼cjkstart阪＼cjkstart織 & 物 & 4,564 & 1,800 & 1,901 & \\
\hline 122 & 日本硝子工弟 & 業 & 4,561 & 2,565 & 248 & \\
\hline 123 & 大 分 紡 繶 & 績 & 4,557 & 1,875 & 1,094 & \\
\hline 124 & + & 組 & $(4,500)$ & & & \\
\hline
\end{tabular}


経営史学

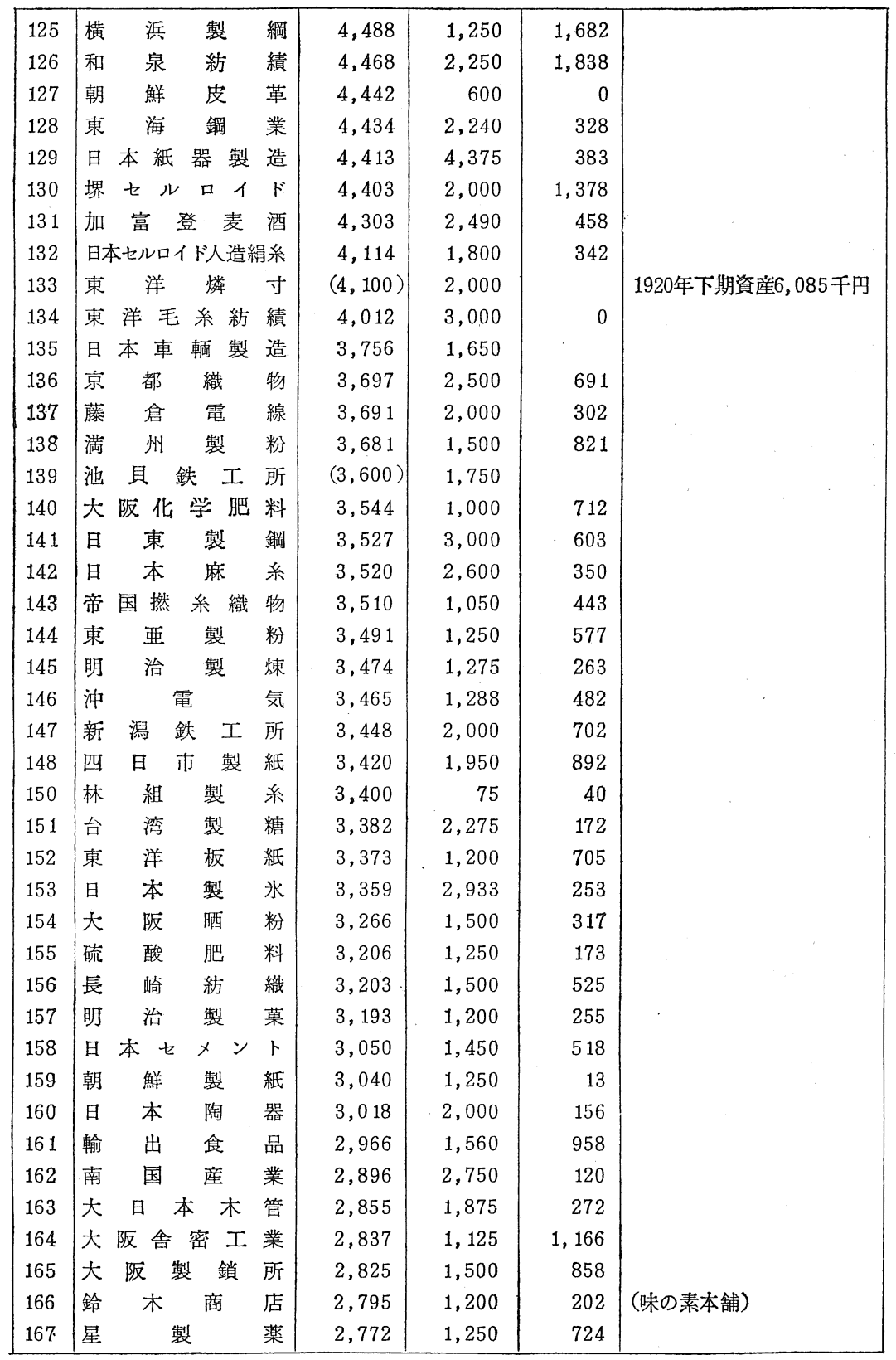


第18巻 第 1 号

\begin{tabular}{|c|c|c|c|c|c|}
\hline 168 & 日 本 光 学 工業 & 2,718 & 2,400 & 216 & \\
\hline 169 & 日 本 絹 布 & 2,706 & 2,500 & 114 & \\
\hline 170 & 愛知 時 計 電 機 & 2,568 & 825 & 249 & \\
\hline 171 & 摄 津 製 油 & 2,556 & 750 & 501 & \\
\hline 172 & 大 阪 毛 織 & 2,529 & 1,000 & 511 & \\
\hline 173 & 森 永 製 荣 & 2,447 & 900 & 53 & \\
\hline 174 & 帝＼cjkstart国＼cjkstart石 & 2,438 & 2,396 & -6 & \\
\hline 175 & 明 電 舎 & 2,391 & 2,000 & & \\
\hline 176 & 豊 田 式 織 機 & 2,390 & 1,080 & 819 & \\
\hline 177 & 浪 花 紡 織 & 2,318 & 750 & 379 & \\
\hline 178 & 佐 賀 紡 織 & 2,301 & 1,200 & 166 & \\
\hline 179 & 東京絹 毛 紡 織 & 2,300 & 1,500 & 22 & \\
\hline 180 & 大日本石油鉱業 & 2,300 & 1,250 & 51 & \\
\hline 181 & 小田原紡 織 & 2,295 & 1,500 & 35 & \\
\hline 182 & 山 陽 紡 織 & 2,288 & 1,250 & 530 & \\
\hline 183 & 南 洋 製 糖 & 2,266 & 1,500 & 144 & \\
\hline 184 & 中 央 製 紙 & 2,232 & 750 & 660 & \\
\hline 185 & 愛知セメント & 2,183 & 1,650 & 214 & \\
\hline 186 & 桜 セメント & 2,164 & 800 & 7.14 & \\
\hline 187 & 日 本 形 染 & 2,147 & 1,100 & 216 & \\
\hline 188 & 戸 畑 鋳 物 & $(2,120)$ & 2,000 & & 1920年下期資産 3, 170 千円 \\
\hline 189 & 発 動 機 製 造 & 2,114 & 625 & 157 & \\
\hline 190 & 亜 鉛 電 解 鉱 業 & 2,069 & 1,498 & 50 & \\
\hline 191 & 佐賀七メント & 2,064 & 800 & 215 & \\
\hline 192 & 大 日 本製 薬 & 2,040 & 700 & 463 & \\
\hline 193 & 中 央 石 油 & 2,037 & 1,000 & 505 & \\
\hline 194 & 極 東 硝 子 & 2,031 & 750 & 93 & \\
\hline 195 & 紀 陽 織 布 & 1,965 & 1,060 & 659 & \\
\hline 196 & 日本楽 器製造 & 1,962 & 900 & 224 & \\
\hline 197 & 木 曾 興 業 & 1,961 & 825 & 389 & \\
\hline 198 & 安 来 製 鋼 所 & 1,845 & 750 & 198 & \\
\hline 199 & 台 湾 製 麻 & 1,794 & 500 & 210 & \\
\hline 200 & $\begin{array}{c}\text { 日本火薬製 造 } \\
\text { 〔別 }\end{array}$ & 1,776 & 1,000 & & \\
\hline & 三 菱 鉱 業 & 66,143 & 40,000 & 8,242 & \\
\hline & 三 并 鉱 山 & $63, .062$ & 30,500 & 15,254 & \\
\hline
\end{tabular}




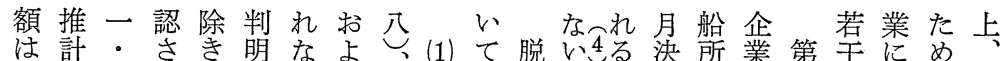

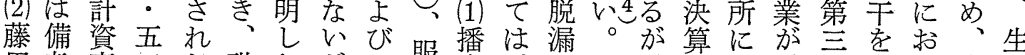
田考隡严た職たが服磨、に、、書は、に含け推産 鉱欄を倍。工企、畑部造推つ既でそ決、める計能 業に算に一数業大鋳商船定い述はの算藤、地を力 記出増九唯で正物店所ので

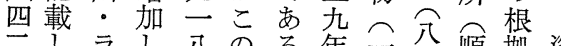

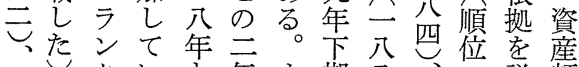
北。ク方年ま期分等説額

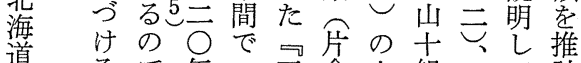
道製こで年二杢倉七組片て計

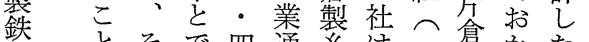

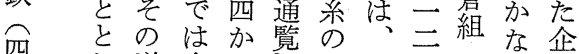

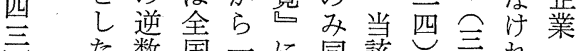
述は頗苗研垃断に た卞加料造究は念つ 対造、怔船を重しい 象船三え所継要たて 企开开続な。も 業場物れ旭しのだ正 の鏟な造たでが確 範勘のい船い、、な 囲定造ま所と個こ数 に五船まな考人の学 入○部にどえな時を ら○少脱実てい期 な・市漏質いしのる 野 天の姜六れ年期東しばカ

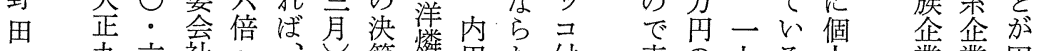
醬九六社へ、算㶤田な付表の九る人業業困 油年七のの内の数寸造い表示数二。企のの難

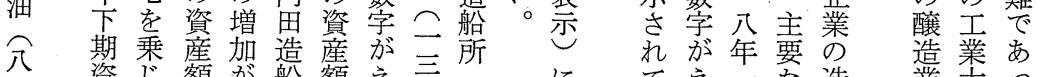

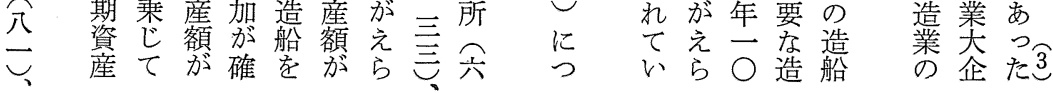

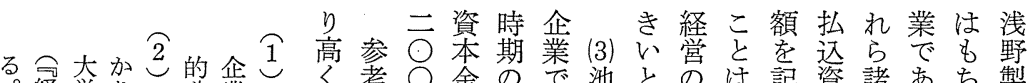

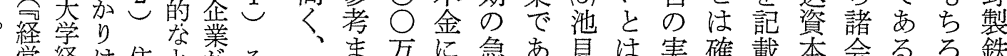
営経

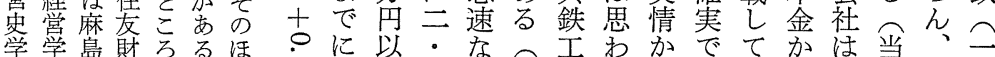

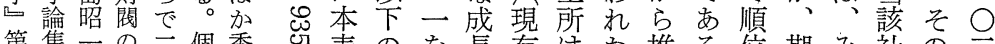

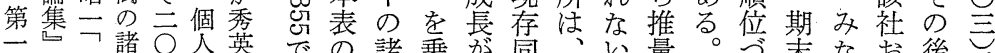

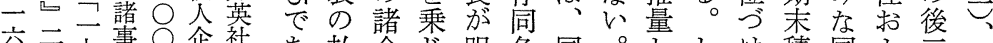
巻西九業社業卯

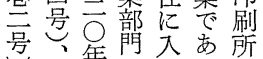
に同以のるって博

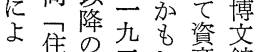
○隻住三し産 館 て灰集二れ額 館 あ払会し明名同。乙しけ積同よ豆服 る。込社て ら会様て加た咅年び年服 資の推か社に、し金加後間部 本、計なに前実野だの前継以計 金資しのも後際田加記年会上詀 资産たで存期醬ら録に社の店 資額。、在の資油帮の設に決气 産と乗 (2) せ決産孝数あ立む算二 要閥財年なはよ確ら類払数と算 るに閥以以確 程沶に降。認に 度け関の瓷職 える瓷資方立数

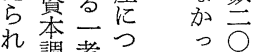
る調考察て た に達察て 架人

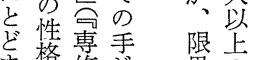
の込注区范数 と<順もれ存料 入 率龺同乞同唹のと位のたしがの

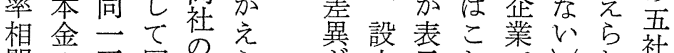
関の五同の場方立示れ芯しれ社 係比 $\bigcirc$ 社場れら、期ををあななは 数率万召合な その去妿るた㔔当 注あ゙円み払こ加机経ま算のだした当 なる上込のた寺やるた、こ企期 
払の書にのら東屋三

込実括、決に洋商 $\vec{\bigcirc}$ 第

資翼よ営算商経店○至

本的び寀收蓝済調社表

二は查報会信報部あ

五同可告社所社可る一

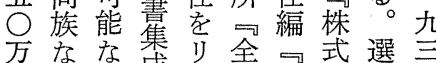

円諸成王罢株年択

以し機等占諸式鑑の手照

上家関第ア会年手照

約所蔵 |プ役箩和き五

三有の第乙員第公亡

六の営四た録九年し年

諸業集。回度て下

社会報采昭版は期

調社告所の和昭害收基标

查直学の公六同本け

乙接調当、度年書文る

問租該第・院献最

本々し期云同を刊と夲

表合、営表七用しし志

をわ非業と年いおて業

作世公報同度、よ大企

成、開告様版さび阪業

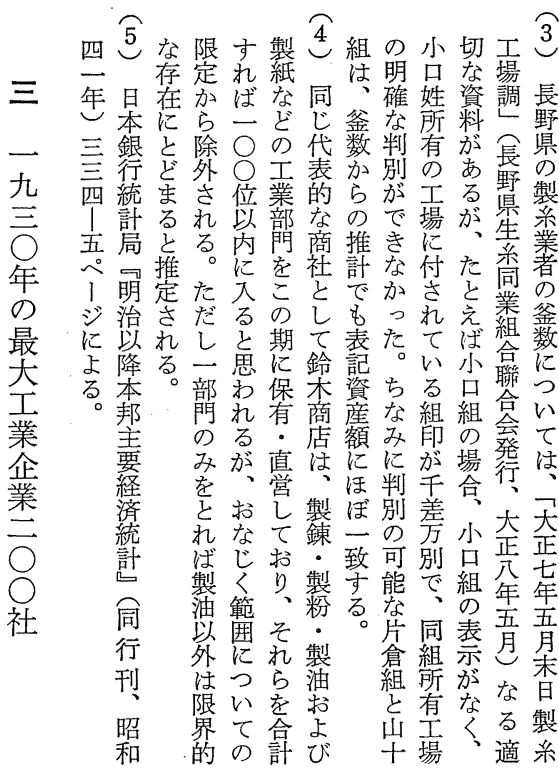

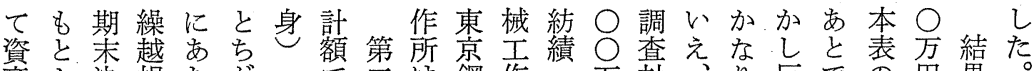
産よ決損たが一で主鋼作・万対、り反での円果 額り算学りっ社表表四材所三向象第多面京場以的 を可額計、てを示で 焂能に上約二例しは○大旭紡上業表。資の、洼

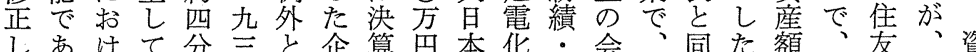

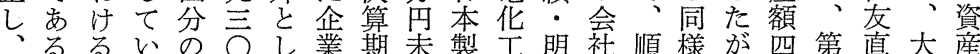
改。こる。年て浮に満薬業治に位にっ○二系企額

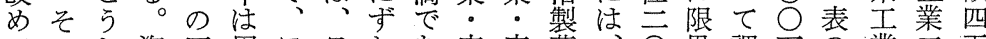
てこし資五周ほ日れあ帝帝菓、○界調万の業元五 作でた産三知か本のる国国・ち三的香豼住諸 ○五 成修欠評社のに足あ。炎然京な位な対以友部门万 し正損価がよは袋る薬系都み以層象上の鹏. 社円 たが注の期うなな企な織織に卡芷五よがと以 の必こ水素に、ブ業に゙物物藤のの業○う株し上 が要れ増にい。リが

、加をし炎わも流若 第つ減は損ゆつ市 可額こなるとトあ 表能修れい昭もンる のな正をし和、タが 最企于別乞恐一个 大業ると謊九ヤ資

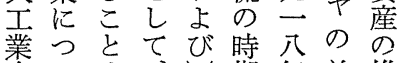
企い注、期年前推 が・・沢資脱は○な式て あ天日薬産漏第万大会選払 り満本品四怔一円社択込 、織染。五あ表未なと資 資物料徳五るよ満脱し表本 生・製山元加の漏て示金 堂泉造鉄円も多会は設さは 州宁板未しか社なっ立れほ 小織大: 満れつの、1さてぼ 松物阪富、なた数。れい三 製・機山四、をはしたる 
経営史学

第 2 表 最大工業200社；1930(昭和 5)年 [A]

（単位: 1,000 円）

\begin{tabular}{|c|c|c|c|c|c|c|}
\hline 順位 & 社 & & 資 産 & 払込資本金 & 利 益 & 備 \\
\hline 1 & 川 崎 造 船 & 所 & $\because 252,045$ & 74,250 & $-6,966$ & \\
\hline 2 & 士＼cjkstart製 & 紙 & 156,277 & 58,925 & 5,010 & \\
\hline 3 & 子 & 紙 & 154,473 & 48,682 & 7,345 & \\
\hline 4 & 鐘 & 績 & 129,572 & 28,596 & 8,999 & \\
\hline 5 & 樺 太 I & 業 & 125,208 & 53,389 & 2,711 & \\
\hline 6 & 日本窒素肥 & 料 & 122,924 & 39,248 & 4,958 & \\
\hline 7 & 大 日 本 紡 & 績 & 113,089 & 52,000 & 4,721 & \\
\hline 8 & 大 日 本 製 & 糖 & 111,537 & 34,749 & 3,807 & \\
\hline 9 & 本．石 & 油 & 107,705 & 56,000 & 3,479 & \\
\hline 10 & 東 洋 紡 & 績 & 106,111 & 36,850 & 8,782 & \\
\hline 11 & 台 湾 製 & 糖 & 103,723 & 43,080 & 5,686 & \\
\hline 12 & 菱 造 & 船 & 96,369 & 30,000 & 1,571 & \\
\hline 13 & 塩 水 港 製 & 糖 & $\% 91,185$ & 17,438 & -13 & \\
\hline 14 & 浅 野 セ メ ン & $卜$ & 90,242 & 53,988 & 1,909 & \\
\hline 15 & 大 日 本麦 & 酒 & 82,660 & 50,000 & 9,153 & \\
\hline 16 & 朝 鮮 窯 素 肥 & 料 & 81,334 & 30,000 & 54 & 1930年.上期 \\
\hline 17 & 日本 毛 & 織 & 77,484 & 27,500 & 4,407 & \\
\hline 18 & 大日本人造肥 & 料 & 75,021 & 26,800 & 1,586 & \\
\hline 19 & 富士瓦斯 紡 & 績 & $※ 72,179$ & 34,000 & $-3,363$ & \\
\hline 20 & 明. 治 製 & 糖 & 67,269 & 34,800 & 4,622 & \\
\hline 21 & 片 倉製 系 紡 & 績 & 61,618 & 26,375 & 10,060 & \\
\hline 22 & 日本 鉱 & 業 & 59,477 & 50,000 & 970 & \\
\hline 23 & 魯 & 業 & $※ 56,846$ & 22,750 & $-1,680$ & \\
\hline 24 & 同 毛 & 織 & $\% 53,181$ & 25,000 & $-1,043$ & \\
\hline 25 & 浅 野 造 船 & 所 & $※(50,512)$ & 25,000 & 172 & $\begin{array}{l}\text { 1932年上期，ほ加繰越損失 } \\
\text { 14，863干円 }\end{array}$ \\
\hline 26 & 日 本 製，鋼 & 所 & 50,001 & 30,000 & 1,052 & \\
\hline 27 & 神 戸 製 鋼 & 所 & 48,910 & 20,000 & 2,812 & \\
\hline 28 & 十 製 & 系 & $※ 47,099$ & 12,500 & $-5,551$ & $\begin{array}{l}\text { 1929年決算, 損失は(繰越 } \\
\text { 損却一利会〕算 }\end{array}$ \\
\hline 29 & 内 外 & 綿 & 46,569 & 16,000 & 2,824 & \\
\hline 30 & 大 日 本製 方 & 水 & 46,218 & $28,67 \dot{6}$ & 3,995 & \\
\hline 31 & 大阪合 同 紡 & 績 & 45,031 & 18,750 & 7,989 & \\
\hline 32 & 製 & 薬 & $\% 44,133$ & 6,000 & -961 & \\
\hline 33 & 三 菱 製 & 鉄 & 41,622 & 25,000 & 0 & \\
\hline 34 & 電気化学工 & 業 & 39,307 & 17,500 & 723 & \\
\hline 35 & 釜石鉱 & 山 & $※ 39,136$ & 20,000 & -93 & \\
\hline 36 & 本 & 管 & $※ 38,068$ & 15,225 & -352 & \\
\hline 37 & 古 河 鉱 & 業 & 37,535 & 22,500 & 1,376 & \\
\hline 38 & 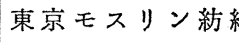 & 織 & 37,006 & 10,381 & 154 & \\
\hline 39 & 倉 敷 紡 & 績 & $※ 36,706$ & 12,350 & $-1,395$ & \\
\hline 40 & 日 本 & 業 & $※ 36,343$ & 9,496 & -653 & \\
\hline
\end{tabular}




\begin{tabular}{|c|c|c|c|c|c|}
\hline 41 & 東 京 電 気 & 36,312 & 21,000 & 9,391 & \\
\hline 42 & 小野田セメント製造 & 35,944 & 21,815 & 1,602 & \\
\hline 43 & 帝 国 製 麻 & $※ 35,872$ & 10,675 & -148 & \\
\hline 44 & 東京瓦斯電気工業 & 35,454 & 5,250 & -15 & \\
\hline 45 & $\begin{array}{lll}\text { 日 } & \text { 清 } \quad \text { 紡 } & \text { 績 }\end{array}$ & 35,408 & 18,300 & 3,064 & \\
\hline 46 & 帝国人造絹系 & 35,401 & 21,000 & 6,469 & \\
\hline 47 & 帝 国 製 糖 & 34,584 & 13,500 & 1,712 & \\
\hline 48 & 東 洋 製 鉄 & 33,739 & 30,600 & 342 & \\
\hline 49 & 野＼cjkstart田＼cjkstart賣 & 33,110 & 26,250 & 931 & \\
\hline 50 & 大 阪 鉄 工 所 & $※ 32,027$ & 10,500 & 264 & \\
\hline 51 & 芝 浦 製 作 所 & $※ 31,136$ & 6,330 & $-1,685$ & \\
\hline 52 & 日 本 製 粉 & 29,746 & 3,938 & 385 & \\
\hline 53 & 住友別子鉱山 & $※ 29,124$ & 15,000 & -13 & \\
\hline 54 & 郡 是 製 糸 & 29,218 & 11,717 & 4,820 & \\
\hline 55 & 日 華 紡 & 28,164 & 8,800 & 764 & \\
\hline 56 & 日 清 製 紛 & 27,903 & 9,402 & 1,501 & \\
\hline 57 & 上海製造 絹 系 & 27,644 & 10,000 & 2,344 & \\
\hline 58 & 日本麦酒鉱泉 & 27,614 & 13,994 & 1,483 & \\
\hline 59 & 古河電気 工業 & 27,440 & 12,500 & 1,612 & \\
\hline 60 & 日 本 電 気 & 25,510 & 15,000 & 1,450 & \\
\hline 61 & 昭 和 製 鋼 所 & 25,420 & 25,000 & 189 & \\
\hline 62 & 日 立 製 作 所 & 24,654 & 10,000 & 1,257 & \\
\hline 63 & 旭硝 & 24,017 & 6,875 & 694 & \\
\hline 64 & 川 崎 車 & 23,633 & 12,000 & 968 & \\
\hline 65 & 福島絖 & 23,490 & 5,600 & 1,078 & \\
\hline 66 & 藤 田 鉱 & 22,717 & 5,000 & -90 & \\
\hline 67 & 豊＼cjkstart年＼cjkstart製 & 22,520 & 10,000 & 46 & \\
\hline 68 & 三菱 航 空 & 22,005 & 5,000 & 612 & \\
\hline 69 & 東＼cjkstart京＼cjkstart製 & $\cdot 21,874$ & 8,500 & 828 & \\
\hline 70 & 横 浜 船 & 21,795 & 5,000 & 623 & \\
\hline 71 & 台 南 製 & $※ 21,762$ & 10,000 & -198 & \\
\hline 72 & 麒＼cjkstart麟＼cjkstart麦 & 21,656 & 8,300 & 1030 & \\
\hline 73 & 住友伸 銅 鋼 管 & 21,196 & 12,000 & 154 & \\
\hline 74 & 東洋 レーヨ & 21,166 & 10,000 & 165 & \\
\hline 75 & 東洋モスリン & $※ 21,027$ & 13,800 & -406 & \\
\hline 76 & 新＼cjkstart高＼cjkstart製 & 20,872 & 10,500 & 577 & \\
\hline 77 & 森 永 製 菓 & 20,575 & 13,800 & 806 & \\
\hline 78 & 三 菱 電 機 & 20,378 & 10,500 & 59 & \\
\hline 79 & 住友電線製 造所 & 20,048 & 10,000 & 1,485 & \\
\hline 80 & 岸和 田紡 績 & 19,880 & 6,186 & 539 & \\
\hline 81 & 三 共 & 18,388 & 7,840 & 1,411 & \\
\hline 82 & 磐城 七 メ & 17,858 & 9,062 & 258 & \\
\hline
\end{tabular}


経営史学

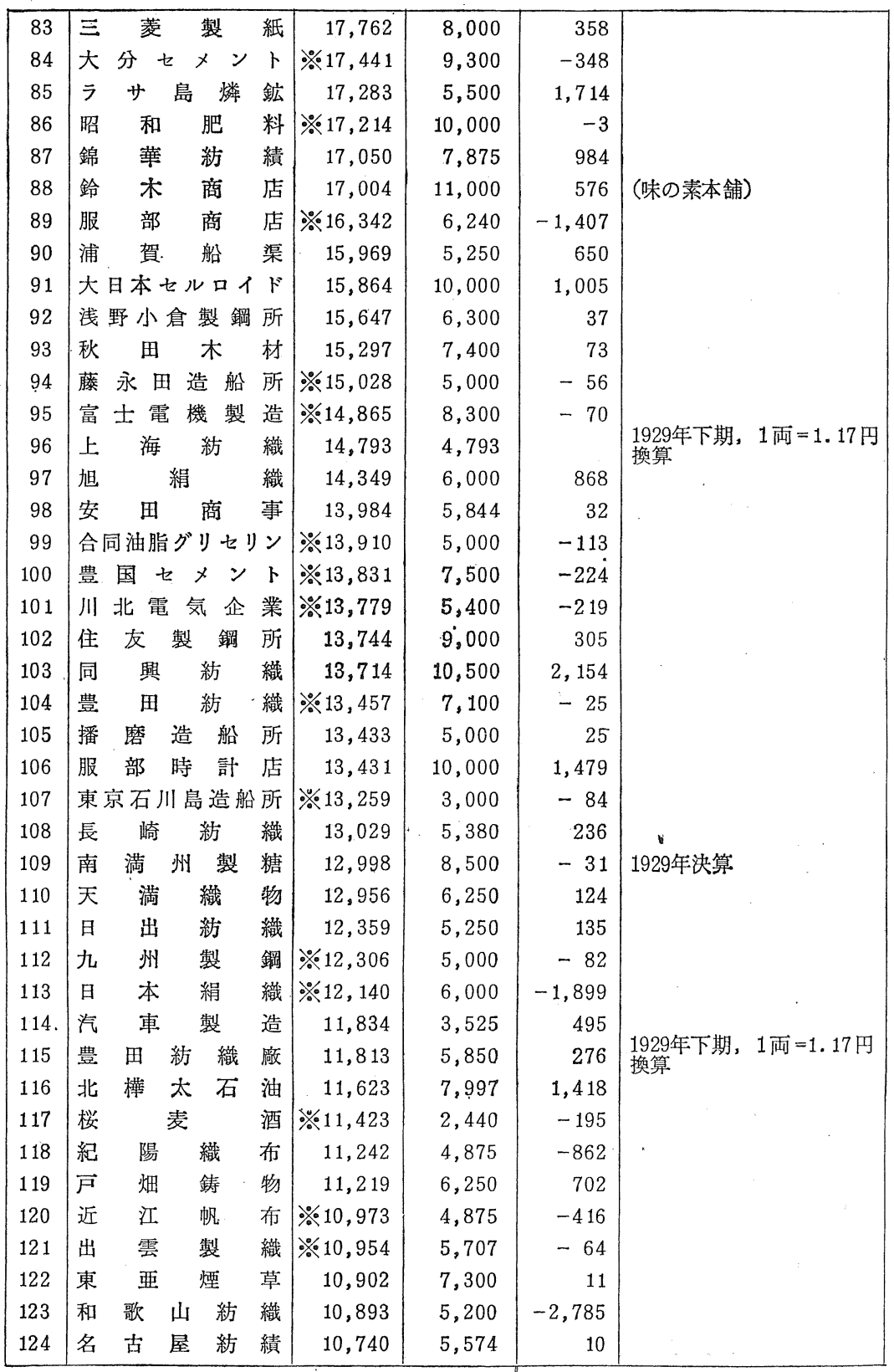


第18巻 第 1 号

\begin{tabular}{|c|c|c|c|c|c|}
\hline 125 & 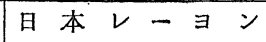 & 10,670 & 7,500 & 330 & \\
\hline 126 & 武田長兵衛商店 & 10,557 & 5,300 & & \\
\hline 127 & 日本 製 布 & $\% 10,436$ & 1,500 & -331 & \\
\hline 128 & 日 本 樟 脸 & 10,080 & 6,750 & 554 & \\
\hline 129 & 秩父七メント & 10,021 & 4,750 & 256 & \\
\hline 130 & 日本セメント & 9,772 & 5,688 & 129 & \\
\hline 131 & 中 央毛糸紡 績 & 9,748 & 4,000 & 525 & \\
\hline 132 & 昭 和 $\nu$ - & 9,412 & 7,800 & 605 & \\
\hline 133 & 内 海 紡 織 & 9,364 & 2,500 & 8 & \\
\hline 134 & 土佐セメント & $\propto 9,299$ & 6,400 & -86 & \\
\hline 135 & 日本車輛製造 & 9,210 & 6,250 & 859 & \\
\hline 136 & 昭和毛系紡 績 & 9,204 & 8,000 & 256 & \\
\hline 137 & 日 本 皮 革 & 8,721 & 5,000 & 765 & \\
\hline 138 & 朝 鮮 紡 & $※ 8,581$ & 5,000 & 0 & \\
\hline 139 & 和 泉 紡 & 8,562 & 4,500 & 1,145 & \\
\hline 140 & 北 越 製 紙 & 8,492 & 4,050 & 369 & \\
\hline 141 & 宇部セメント製造 & 8,429 & 5,075 & 46 & \\
\hline 142 & 福 助 足 袋 & 8,420 & 5,000 & 691 & \\
\hline 143 & 大阪莫大小紡織 & 8,361 & 2,720 & 214 & \\
\hline 144 & 藤 倉 電 線 & 8,078 & 5,000 & 408 & \\
\hline 145 & 華 製 & 7,730 & 4,000 & 8 & \\
\hline 146 & 日 英 䁔 & $※ 7,515$ & 1,977 & $-1,752$ & \\
\hline 147 & 愛知 時計 電 機 & 7,494 & 2,275 & 359 & \\
\hline 148 & 日 清 製 & $※ 7,472$ & 3,750 & -324 & \\
\hline 149 & 新 竹”製 & 7,460 & 2,175 & 14 & \\
\hline 150 & 佐 野 紡 & $※ 7,274$ & 3,750 & -167 & \\
\hline 151 & 日 東 紡 & $※ 7,085$ & 3,925 & 31 & \\
\hline 152 & 菊＼cjkstart井＼cjkstart紡 & $※ 7,066$ & 4,500 & -176 & \\
\hline 153 & 大 島 製 鋼 & 6,779 & 5,438 & -70 & \\
\hline 154 & 新 潟 鉄 工 所 & 6,689 & 4,000 & 539 & \\
\hline 155 & 大阪窯業セメント & 6,652 & 4,500 & 659 & \\
\hline 156 & 共立モスリン & $※ 6,537$ & 4,000 & 0 & \\
\hline 157 & 旭石 & 6,527 & 2,400 & $-3,852$ & 上惿な整埋勋正」そ損大 \\
\hline 158 & 吉＼cjkstart見＼cjkstart紡 & $※ 6,406$. & 4,250 & $-1,290$ & \\
\hline 159 & 多木製 肥 & 6,326 & 3,500 & 136 & \\
\hline 160 & 林＼cjkstart組＼cjkstart製 & $※ 6,242$ & 2,500 & -177 & 1929年決算 \\
\hline 161 & 塭 野 義 商 & 6,212 & 2,700 & 279 & \\
\hline 162 & 満＼cjkstart州＼cjkstart紡 & $※ 6,131$ & 3,750 & -76 & \\
\hline 163 & 電 & 6,095 & 3,500 & & \\
\hline 164 & 阪織 & 6,050 & 3,000 & 18 & \\
\hline 165 & 沖＼cjkstart電 & 6,046 & 3,500 & 219 & \\
\hline 166 & 日 本 板 硝 & 5,953 & 3,250 & 276 & \\
\hline
\end{tabular}


経営史学

\begin{tabular}{|c|c|c|c|c|c|}
\hline 167 & 伊 丹 製 䄉 所 & 5,922 & 2,625 & 429 & \multirow{23}{*}{$\begin{array}{l}\text { 1930年12月設立, 翌年上期 } \\
\text { 決算 }\end{array}$} \\
\hline 168 & 久保田鉄工所 & 5,919 & 3,550 & 366 & \\
\hline 169 & 日本楽 器製 造 & 5,901 & 2,625 & 296 & \\
\hline 170 & 池 具 鉄 工 所 & 5,873 & 3,400 & 339 & \\
\hline 171 & 秀 英 舎 & 5,840 & 3,000 & 366 & \\
\hline 172 & 七尾セメント & 5,836 & 2,750 & 5 & \\
\hline 173 & 倉 敷 絹 $\quad$ 織 & 5,834 & 3,500 & 248 & \\
\hline 174 & 中 & 5,832 & 3,700 & 206 & \\
\hline 175 & 相 & $※ 5,721$ & 2,035 & -132 & \\
\hline 176 & 富 士 製 & $※ 5,706$ & 3,100 & -96 & \\
\hline 177 & 日本ペイント & 5,643 & 3,600 & 390 & \\
\hline 178 & 満 蒙 毛 織 & $※ 5,623$ & 1,950 & -56 & \\
\hline 179 & 日 本 自 動 & 5,621 & 1,710 & 109 & \\
\hline 180 & 花王石簽長瀬商会 & 5,516 & 3,000 & 615 & \\
\hline 181 & 旭 紡 織 & 5,504 & 2,640 & 56 & \\
\hline 182 & 大日本石油鈗業 & $※ 5,451$ & 4,737 & -24 & \\
\hline 183 & 品 川 白 棟 瓦 & 5,443 & 3,500 & 137 & \\
\hline 184 & 辻 紡 績 & $※ 5,420$ & 3,000 & -134 & \\
\hline 185 & 東京計器製 作所 & 5,216 & 2,700 & 576 & \\
\hline 186 & 新 興 毛 織 & 5,174 & 2,500 & 468 & \\
\hline 187 & 大 日 本塩 & 5,119 & 3,803 & 238 & \\
\hline 188 & 阪＼cjkstart紡 & $※ 5,035$ & 2,802 & -216 & \\
\hline 189 & 東 & 5,010 & 1,750 & 533 & \\
\hline 190 & 足 & $(5,000)$ & 5,000 & & \multirow{15}{*}{$\begin{array}{l}\text { 1931年 3月ブリ ジストンタ } \\
\text { イヤに改組時の資本金 } \\
\text { (サントリー) }\end{array}$} \\
\hline 191 & 寿 & 4,963 & 1,600 & 283 & \\
\hline 192 & 毛 & 4,912 & 2,000 & 6 & \\
\hline 193 & 国冷 & 4,839 & 2,883 & 409 & \\
\hline 194 & 豊 田 式 織 & 4,781 & 2,175 & 1,279 & \\
\hline 195 & 海＼cjkstart鍋 & 4,780 & 2,250 & 99 & \\
\hline 196 & 東華紡 & 4,725 & 2,400 & 334 & \\
\hline 197 & 本伸 & 4,720 & 2,250 & 86 & \\
\hline 198 & 阪 & 4,579 & 3,000 & 533 & \\
\hline 199 & 利 & $※ 4,577$ & 1,750 & -142 & \\
\hline 200 & 住 友 肥 & 4,569 & 1,800 & 64 & \\
\hline 201 & 函館 船 & 4,554 & 3,200 & 165 & \\
\hline & 〔別表〕 & & & & \\
\hline & 三 菱 鉱 業 & 137,116 & 62,500 & 4,624 & \\
\hline & 三 井 鉱 山 & 111,826 & 62,500 & 4,953 & \\
\hline
\end{tabular}


第18巻 第 1 号

第 3 表 最大工業企業 200 社：1930(昭和 5 ) 年 [B]

（単位：1,000円）

\begin{tabular}{|c|c|c|c|c|}
\hline 順位 & 社 & 総資産（修正） & 備 & 考 \\
\hline 1 & 川 崎 造 船 所 & 233,991 & & \\
\hline 2 & 富 士 製 紙 & 156,277 & & \\
\hline 3 & 王 子 製 紙 & 154,473 & & \\
\hline 4 & $\begin{array}{lll}\text { 鐘 淵 紡 績 } \\
\end{array}$ & 129,572 & & \\
\hline 5 & 樺 太 工 業 & 125,208 & & \\
\hline 6 & 日本窒素肥 料 & 122,924 & & \\
\hline 7 & 大 日 本 紡 績 & 113,087 & & \\
\hline 8 & 大 日 本 製 糖 & 111,537 & & \\
\hline 9 & 日本 石 油 & 107,705 & & \\
\hline 10 & 東 洋 紡 績 & 106,111 & & \\
\hline 11 & 台 湾 製 糖 & 103,723 & & \\
\hline 12 & 三 菱 造 船 & 96,369 & & \\
\hline 13 & 塩 水 港 製 糖 & 91,447 & & \\
\hline 14 & 浅 野 セメント & 90,242 & & \\
\hline 15 & 大 日 本 麦 酒 & 82,660 & & \\
\hline 16 & 朝 鮮 窒素肥 料 & 81,344 & & \\
\hline 17 & 日 本 毛 織 & 77,484 & & \\
\hline 18 & 大日本人造肥料 & 75,021 & & \\
\hline 19 & 富士瓦斯 紡 績 & 69,795 & & \\
\hline 20 & 明 治 製 糖 & 67,269 & & \\
\hline 21 & 片 倉製 系 紡 績 & 61,618 & & \\
\hline 22 & 日 本 鉱 業 & 59,477 & & \\
\hline 23 & 日 魯 漁 業 & 55,870 & & \\
\hline 24 & 日 本 製 鋼 所 & 50,001 & & \\
\hline 25 & 神 戸 製 鋼 所 & 48,910 & & \\
\hline 26 & 内 外綿 & 46,569 & & \\
\hline 27 & 大日本製 水 & 46,218 & & \\
\hline 28 & 大阪合同紡 績 & 45,031 & & \\
\hline 29 & 三 菱 製 鉄 & 41,622 & & \\
\hline 30 & 山 + 製 系 & $(41,263)$ & 1929年決算 & \\
\hline 31 & 電気 化学工業 & 39,307 & & \\
\hline 32 & 日 本 鋼 管 & 37,726 & & \\
\hline 33 & 古 河 鉱 業 & 37,535 & & \\
\hline 34 & 釜石鉱 山 & 37,336 & & \\
\hline 35 & 東京モスリン紡織 & 37,006 & & \\
\hline 36 & 東 京 電 気 & 36,312 & & \\
\hline 37 & 小野、田セメント製造 & 35,944 & & \\
\hline 38 & 浅 野 造 船 所 & $(35,821)$ & 1932年上期 & \\
\hline 39 & 帝 国 製 麻 & 35,724 & & \\
\hline 40 & 東京瓦斯電気工業 & 35,454 & & \\
\hline
\end{tabular}


経営史 学

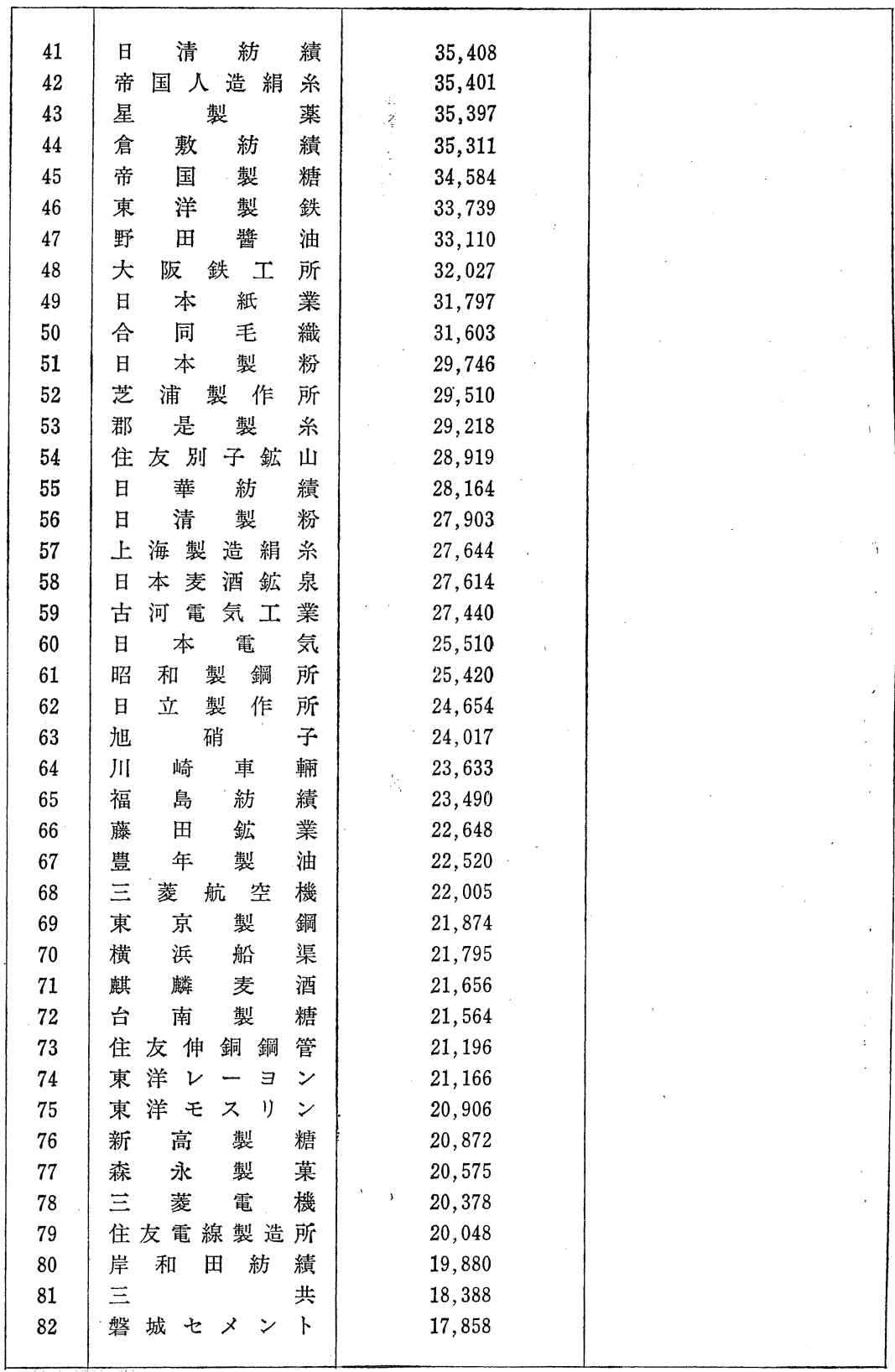


第18巻 第 1 号

\begin{tabular}{|c|c|c|c|}
\hline 83 & 三 菱 製 紙 & 17,762 & \multirow{42}{*}{ 1929年下期 } \\
\hline 84 & ラ サ 島 燐 礦 & 17,283 & \\
\hline 85 & 昭 和 肥 料 & 17,190 & \\
\hline 86 & 大分 セメント & 17,075 & \\
\hline 87 & $\begin{array}{lll}\text { 錦 華 紡 績 }\end{array}$ & 17,050 & \\
\hline 88 & 鈴 木 商 店 & 17,004 & \\
\hline 89 & 播 磨 造 船 所 & $(16,965)$ & \\
\hline 90 & 浦 賀 船 渠 & 15,969 & \\
\hline 91 & 大日本セルロイド & 15,864 & \\
\hline 92 & 浅野小倉製鋼所 & 15,647 & \\
\hline 93 & 秋 田 木 材 & 15,297 & \\
\hline 94 & 服 部 商 店 & 14,992 & \\
\hline 95 & 藤 永田造 船 所 & 14,891 & \\
\hline 96 & 上 海 紡 織 & 14,793 & \\
\hline 97 & 旭絹織 & 14,349 & \\
\hline 98 & 安 田 商 事 & 13,984 & \\
\hline 99 & 合同油脂グリセリン & 13,798 & \\
\hline 100 & 住犮製 鋼 所 & 13,741 & \\
\hline 101 & 同 興 紡 織 & 13,714 & \\
\hline 102 & 富士電 機 製 造 & 13,644 & \\
\hline 103 & 豊国セメント & 13,607 & \\
\hline 104 & 豊 田 紡 織 & 13,432 & \\
\hline 105 & 服 部 時 計 店 & 13,431 & \\
\hline 106 & 東京石川島造船所 & 13,175 & \\
\hline 107 & 長 崎 紡 織 & 13,029 & \\
\hline 108 & $\begin{array}{lll}\text { 天 満 織 物 } & \end{array}$ & 12,956 & \\
\hline 109 & 川 北電気 企 業 & 12,824 & \\
\hline 110 & 日 出 紡 織 & 12,359 & \\
\hline 111 & 汽 車 製 & 11,834 & \\
\hline 112 & 豊 田 紡 織 廠 & 11,813 & \\
\hline 113 & 北 樺 太 石 油 & 11,623 & \\
\hline 114 & 桜＼cjkstart麦 & 11,228 & \\
\hline 115 & 户＼cjkstart畑＼cjkstart鋳 & 11,219 & \\
\hline 116 & 東＼cjkstart亜＼cjkstart煙 & 10,902 & \\
\hline 117 & 名 古 屋 紡 績 & 10,740 & \\
\hline 118 & 近＼cjkstart江＼cjkstart帆 & 10,715 & \\
\hline 119 & 日 本 レーヨン & 10,670 & \\
\hline 120 & 武田長兵衛商店 & 10,557 & \\
\hline 121. & 和 歌 山 紡 織 & 10,553 & \\
\hline 122 & 日 本 絹 織 & 10,505 & \\
\hline 123 & 日 本 樟 脳 & 10,080 & \\
\hline 124 & 秩 父セメント & 10,001 & \\
\hline
\end{tabular}


経営史学

\begin{tabular}{|c|c|c|c|}
\hline 125 & 日 本セメン・ト & 9,772 & \\
\hline 126 & 中央毛糸紡績 & 9,748 & \\
\hline 127 & 昭和 レーヨン & 9,412 & \\
\hline 128 & 内 海 紡 “織 & 9,364 & \\
\hline 129 & 土佐 セメント & 9,213 & \\
\hline 130 & 日 本 車 輛製 造 & 9,210 & . \\
\hline 131 & 昭 和 毛 糸 紡 績 & 9,204 & \\
\hline 132 & 日 本 製 布 & 9,048 & \\
\hline 133 & 日 本 皮 革 & 8,721 & \\
\hline 134 & 和 泉 紡 績 & 8,562 & \\
\hline 135 & 紀＼cjkstart陽＼cjkstart織 & 8,558 & \\
\hline 136 & 出 雲 製 織 & 8,530 & \\
\hline 137 & 北 越 製 紙 & 8,492 & \\
\hline 138 & 宇部セメント製造 & 8,429 & \\
\hline 139 & 朝 鮮 紡 織 & 8,426 & \\
\hline 140 & 福 助 足 袋 & 8,420 & \\
\hline 141 & 大阪莫大小紡織 & 8,361 & \\
\hline 142 & 九 州 製 鋼 & 8,212 & \\
\hline 143 & 藤 倉，電 線 & 8,076 & \\
\hline 144 & 日 華 製 油 & 7,730 & \\
\hline 145 & 愛 知 時 計 電 機 & 7,494 & \\
\hline 146 & 新 竹 製 糖 & 7,460 & \\
\hline 147 & 南 満 州 製 糖 & 7,351 & \\
\hline 148 & 佐 野 紡 績 & 7,187 & \\
\hline 149 & 日 清 製 油 & 7,154 & \\
\hline 150 & 菊 井 紡 織 & 6,999 & \\
\hline 151 & 日 東 紡 績 & 6,889 & \\
\hline 152 & 大 島 製 鋼 所 & 6,779 & \\
\hline 153 & 新 潟 鉄 工 所 & 6,689 & \\
\hline 154 & 大阪窯業セメント & 6,652 & \\
\hline 155 & 共立モスリン & 6,454 & \\
\hline 156 & 多木 製 肥 所 & 6,326 & \\
\hline 157 & 塩 野 義 商 店 & 6,216 & \\
\hline 158 & 明 電 舎 & 6,095 & \\
\hline 159 & 林 組 製 系 & 6,066 & 1929年決算 \\
\hline 160 & 大 阪 織 物 & 6,050 & \\
\hline 161 & 沖 電気 & 6,046 & \\
\hline 162 & 日 本 板 硝 子 & 5,953 & \\
\hline 163 & 伊 丹製 䋐 所 & 5,922 & \\
\hline 164 & 久. 保 田 鉄 工 所 & 5,919 & \\
\hline 165 & 日本楽器製造 & 5,901 & \\
\hline 166 & 池 具 鉄 工 所 & 5,873 & \\
\hline
\end{tabular}


第18巻 第 1 号

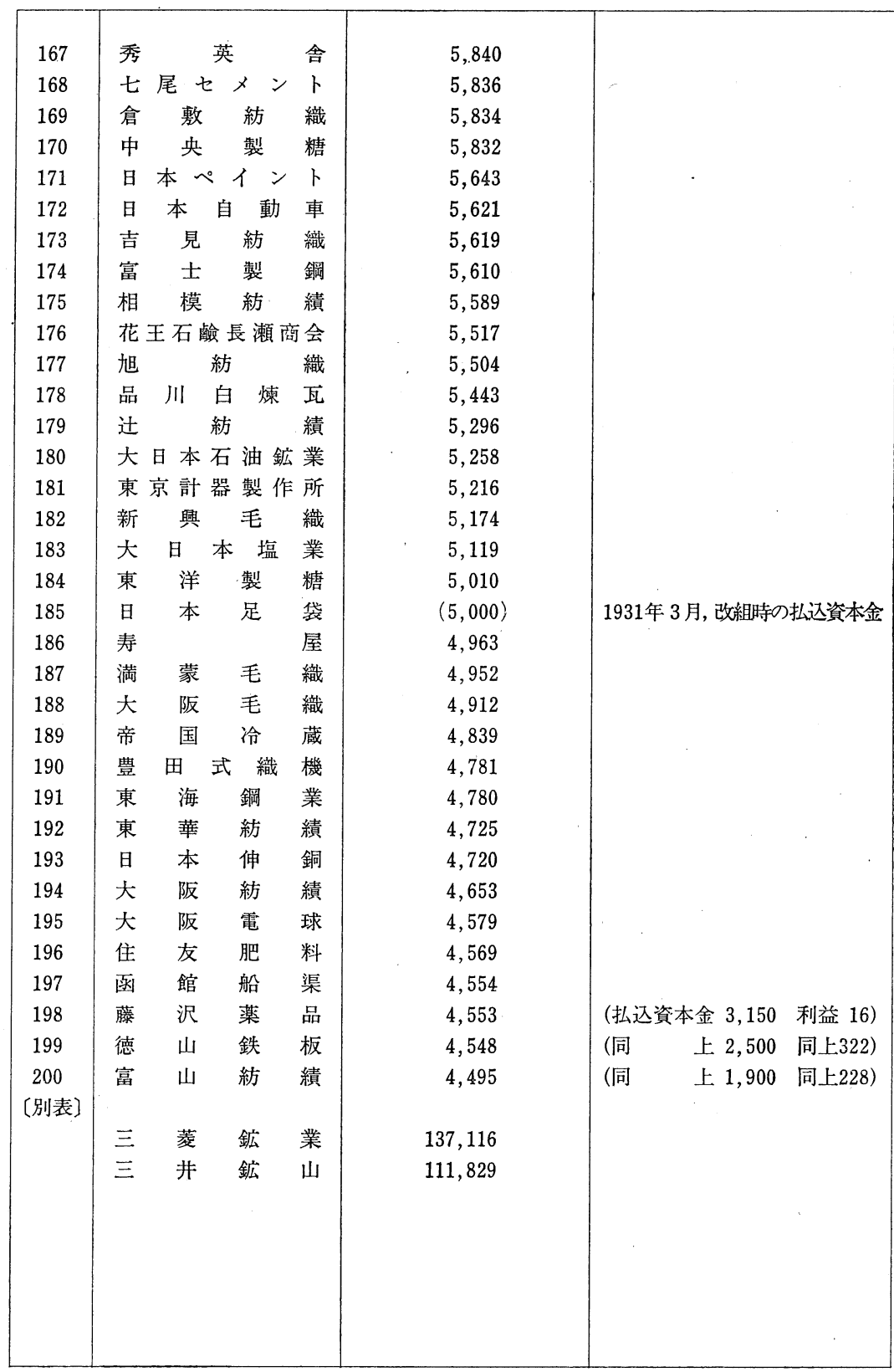


史て当的法同 ○社非まかお

類は時にと社第表卡たんり戦 学可はし九表四の場いすず後 参日非資て五は表作会わるあと 考本上産は公場約年成社ゆ出る。し 乙社会筫版京わ稀経社戦二 た史社 $\overrightarrow{0}$ 産へ証ち戦な済が後九

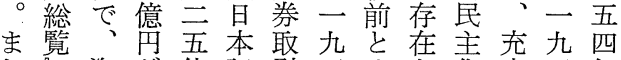
た恣資が億証引五はと化実五年 若経産、以券所四比な. 竐た年選 の済 非莱億アの社上和なの民社のだ 上来界会刊場二らで主年中理 場社以プ社し会九な、化鑑ご闫 会昭上さをに社と戦時類ろ住 の和思る出存筧の㢳息を登らま

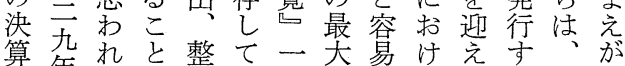
に年るに理い九王とるてる経き つ会なしる。五業な最、よ済に

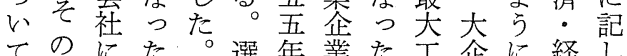
は他つの結出版宁。業業な営た

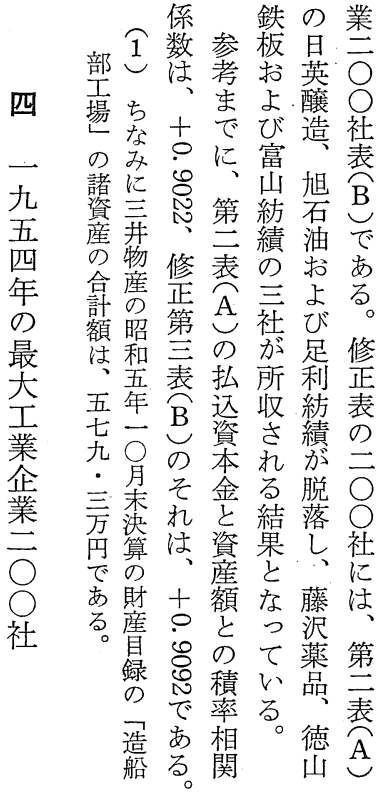

成係の債資けい本う戦 がの一資の本本れき.表な以前

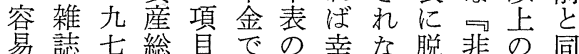
なに ○額のあ場い、落上手様 の類年をなり合で。し場続に で㫦のそか、流読て会き直 の丁ので決、る者い社を接 本資業ま減算戦。のる総へ会 稿産大ま額の前な資覧た社 で順企表処仕の か産兑とに は位業示理方諸で清にい照 揭の文じす，表 そ類え会 載ラ $\bigcirc 、$ れ

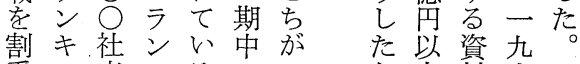
愛当クるのっ表古料六

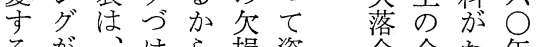
るが、けら、損資会会な年 発すし、金本社社い以 表でた資は金考等の前 さ経產貸は 登全で、に て済貸対ち过稀 お。借照らてい現 り経詨表ん次世在

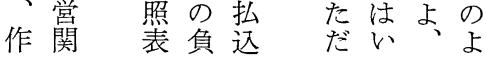


第 4 表 最大工業200社；1954(昭和29)年

第18巻 第 1 号

(単位：100万円)

\begin{tabular}{|c|c|c|c|c|c|c|}
\hline 順位 & 社 & 資産 & 資本金 & 利 益 & 備 & 考 \\
\hline 1 & 八 幡 製，鉄 & 105,544 & 9,600 & 1,633 & & \\
\hline 2 & 製 鉄 & 85,415 & 8,400 & 1,300 & & \\
\hline 3 & 日 本 鋼 管 & 66,671 & 5,000 & 1,805 & & \\
\hline 4 & 日 立 製 作 所 & 49,420 & 6,600 & 2,788 & & \\
\hline 5 & 東 洋 紡 績 & 44,690 & 4,300 & 1,662 & & \\
\hline 6 & 東京芝浦電 気 & 41,799 & 6,000 & 2,421 & & \\
\hline 7 & 新 三菱 重 工業 & 35,895 & 5,600 & 1,351 & & \\
\hline 8 & 鐘 淵 紡 績 & 34,827 & 1,780 & 439 & & \\
\hline 9 & 大 日 本 紡 績 & 34,321 & 5,250 & 1,105 & & \\
\hline 10 & 住发金属工業 & 34,199 & 5,000 & 587 & & \\
\hline 11 & 川 崎 製 鉄 & 33,617 & 4,000 & 433 & & \\
\hline 12 & 三 菱 電 機 & 28,387 & 2,400 & 724 & & \\
\hline 13 & 三 菱 造 船 & 27,902 & 2,800 & 954 & & \\
\hline 14 & 東洋 レーヨン & 24,468 & 3,000 & 2,653 & & \\
\hline 15 & 小野田セメント & 23,483 & 5,120 & 667 & & \\
\hline 16 & 日 産 自 動 車 & 23,210 & 1,400 & 1,025 & & \\
\hline 17 & 日 本 石 油 & 22,500 & 4,500 & 2,064 & & \\
\hline 18 & 昭 和 電 工 & 22,459 & 2,200 & 638 & & \\
\hline 19 & 神 戸 製 鋼 所 & 21,401 & 3,600 & 431 & & \\
\hline 20 & 住 友 化学工業 & 21,273 & 2,000 & 766 & & \\
\hline 21 & 旭 化 成 工 業 & 21,058 & 2,450 & 2,382 & & \\
\hline 22 & 日 立 造 船 & 20,517 & 3,160 & -266 & & \\
\hline 23 & 呉 羽 紡 績 & 19,711 & 1,760 & 200 & & \\
\hline 24 & 太洋 漁 業 & 19,087 & 2,000 & 541 & & \\
\hline 25 & 日 本セメン ト & 19,053 & 2,500 & 767 & & \\
\hline 26 & 日本 毛 & 18,806 & 1,280 & 1,269 & & \\
\hline 27 & 宇 部 興 産 & 18,451 & 2,400 & 974 & & \\
\hline 28 & 三菱日本重工業 & 18,408 & 3,000 & 834 & & \\
\hline 29 & 倉 敷 紡 績 & 18,287 & 2,000 & 572 & & \\
\hline 30 & 旭 硝 子 & 18,281 & 3,100 & 941 & & \\
\hline 31 & 三井金属 鉱業 & 17,468 & 2,400 & 1,229 & & \\
\hline 32 & 三菱 金 属 鉱 業 & 17,377 & 2,100 & 785 & & \\
\hline 33 & 倉 敷 レーヨン & 17,174 & 1,500 & 403 & & \\
\hline 34 & 帝 国人造 絹 糸 & 16,735 & 3,200 & 1,828 & & \\
\hline 35 & 古 河 電気 工業 & 16,284 & 3,000 & 523 & & \\
\hline 36 & 川 崎 重 工 & 16,214 & 3,360 & 409 & & \\
\hline 37 & 十 條 製 & 15,648 & 1,120 & 1,320 & & \\
\hline 38 & 富 士 紡 & 15,633 & 2,000 & 780 & & \\
\hline 39 & 日＼cjkstart東 & 15,102 & 1,350 & 156 & & \\
\hline
\end{tabular}


経 営史 学

\begin{tabular}{|c|c|c|c|c|c|}
\hline 40 & 古 河，鉱 業 & 14,704 & 1,300 & 78 & \multirow{41}{*}{ 利益は上半期 } \\
\hline 41 & 興国人 絹パルプ & 14,395 & 3,000 & 619 & \\
\hline 42 & 石川島重工業 & 14,365 & 1,300 & 413 & \\
\hline 43 & 大 和 紡 績 & 14,060 & 960 & 622 & \\
\hline 44 & 松下電 器産 業 & 14,054 & 3,000 & 1,657 & \\
\hline 45 & 日 産 化学工業 & 14,015 & 2,000 & 871 & \\
\hline 46 & 本 州 製 紙 & 13,726 & 2,000 & 479 & \\
\hline 47 & 武 田薬 品 工業 & 13,722 & 2,100 & 1,003 & \\
\hline 48 & 王子製 紙工業 & 13,646 & 1,600 & 1,624 & \\
\hline 49 & 日 本石 油 精製 & 13,174 & 4,000 & 439 & \\
\hline 50 & 麒 麟 麦 酒 & 13,111 & 1,230 & 1,144 & \\
\hline 51 & 住友金属鉱山 & 13,060 & 1,300 & 397 & \\
\hline 52 & 日 清 紡 績 & 13,039 & 1,040 & 901 & \\
\hline 53 & 三菱 化 成 I 業 & 12,988 & 2,384 & 358 & \\
\hline 54 & 東洋高圧工業 & 12,935 & 1,800 & 1,157 & \\
\hline 55 & 日 本軽 金 属 & 12,923 & 2,046 & 913 & \\
\hline 56 & 山陽パル プ & 12,891 & 2,175 & 853 & \\
\hline 57 & 丸善石油 & 12,594 & 1,050 & 1,069 & \\
\hline 58 & 三 菱 石 油 & 12,280 & 2,400 & 2,005 & \\
\hline 59 & 敷 島 紡 績 & 12,157 & 800 & 316 & \\
\hline 60 & 日 本 製 鋼 所 & 12,104 & 840 & -702 & \\
\hline 61 & いすぶ自動車 & 11,981 & 2,000 & 857 & \\
\hline 62 & 朝 日 麦 酒 & 11,834 & 1,460 & 969 & \\
\hline 63 & 住友電気工業 & 11,561 & 2,000 & 245 & \\
\hline 64 & 出 光 興 産 & 11,381 & 400 & 967 & \\
\hline 65 & 味 . の & 11,266 & 1,640 & 2,210 & \\
\hline 66 & 播 磨 造 船 & 11,245 & 1,000 & -189 & \\
\hline 67 & 日 本 麦 酒 & 11,205 & 1,460 & 882 & \\
\hline 68 & 磐 城 セ メ ント & 11,185 & 800 & 1,695 & \\
\hline 69 & 昭 和 石 油 & 11,114 & 1,700 & 1,321 & \\
\hline 70 & トヨ夕自動車工業 & 10,888 & 1,672 & 1,417 & \\
\hline 71 & 久保田 鉄 工 & 10,402 & 2,520 & 1,185 & \\
\hline 72 & 日 東化学工業 & 10,254 & 2,000 & 769 & \\
\hline 73 & ブリヂストタンイヤ & 10,149 & 2,000 & 334 & \\
\hline 74 & 国策パルプ工業 & 10,120 & 1,200 & 447 & \\
\hline 75 & 東北パル プ & 10,077 & 1,040 & 541 & \\
\hline 76 & 三菱レイヨン & 10,050 & 1,500 & 437 & \\
\hline 77 & 日 亚 製 鋼 & 10,049 & 1,600 & -287 & \\
\hline 78 & 東 洋 工 業 & 9,968 & 300 & 911 & \\
\hline 79 & 富士電機製 造 & 9,830 & 1,500 & 671 & \\
\hline 80 & 近江絹 糸紡 績 & 9,815 & 1,000 & -305 & \\
\hline
\end{tabular}


第18巻 第 1 号

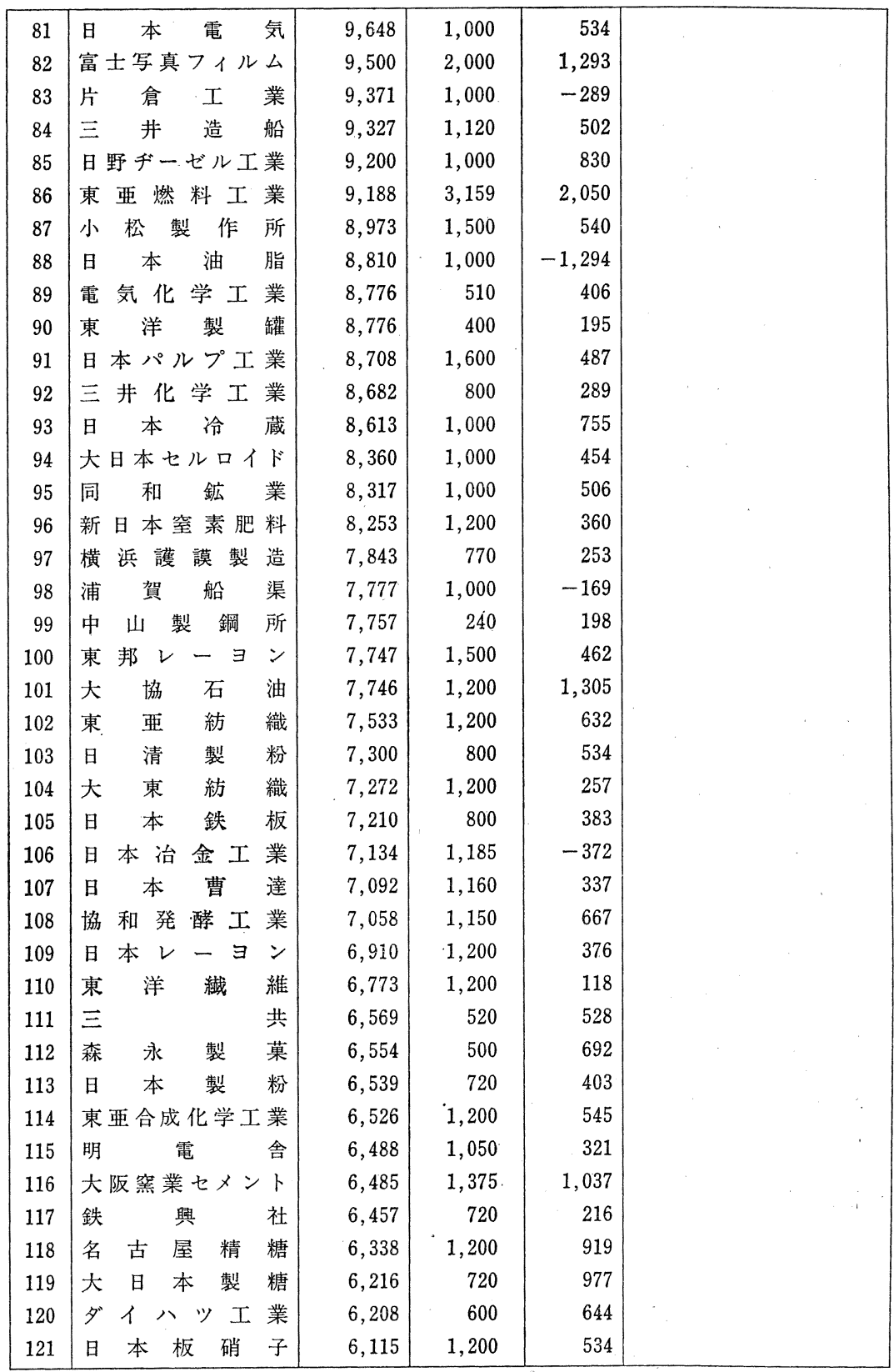


経 営史 学

\begin{tabular}{|c|c|c|c|c|c|}
\hline 122 & 野＼cjkstart田 & 6,082 & 800 & 492 & \\
\hline 123 & 原 & 5,954 & 1,257 & 267 & \\
\hline 124 & 三 & 5,952 & 900 & 227 & \\
\hline 125 & 北越 製 & 5,868 & 900 & -159 & \\
\hline 126 & 宝＜wide>酒 & 5,829 & 2,380 & 1302 & \\
\hline 127 & 倉 電 & 5,758 & 1,056 & 209 & \\
\hline 128 & 是 製 & 5,684 & 500 & 190 & \\
\hline 129 & 大 昭 和 製 紙 & 5,593 & 480 & 354 & \\
\hline 130 & 東洋 曹 達 工業 & 5,423 & 1,000 & 424 & \\
\hline 131 & 不二越鋼材工業 & 5,306 & 1,100 & 11 & \\
\hline 132 & 大 同 毛 織 & 5,277 & 400 & 90 & \\
\hline 133 & 日 本車 輛製 造 & 5,234 & 440 & 301 & \\
\hline 134 & 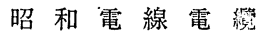 & 5,051 & 1,000 & 216 & \\
\hline 135 & 島 津 製 作 所 & 5,008 & 600 & 303 & \\
\hline 136 & 日＼cjkstart魯＼cjkstart漁 & 4,987 & 1,100 & 207 & \\
\hline 137 & 明 治 製 & 4,927 & 600 & 256 & \\
\hline 138 & 徳 山 曹 達 & 4,867 & 400 & 533 & $:$ \\
\hline 139 & ヤンマーディーゼル & 4,746 & 300 & & \\
\hline 140 & 東 洋 鋼 板 & 4,727 & 240 & 87 & \\
\hline 141 & 小西六写真工業 & 4,710 & 800 & 410 & \\
\hline 142 & 淀 川 製 鋼 所 & 4,690 & 500 & 227 & \\
\hline 143 & 興＼cjkstart巠．石 & 4,660 & 660 & 1004 & \\
\hline 144 & 帝 国 石 油 & 4,657 & 2,000 & 281 & \\
\hline 145 & 塩 野 義 製 薬 & 4,647 & 720 & 297 & \\
\hline 146 & 豊田式自動織機製作所 & 4,617 & 700 & 180 & \\
\hline 147 & 寿 & 4,602 & 58 & & (サントリー). \\
\hline 148 & 帝＼cjkstart国＼cjkstart製 & 4,566 & 720 & 100 & \\
\hline 149 & 尼カ崎 製 & 4,557 & 570 & 155 & \\
\hline 150 & 三＼cjkstart菱＼cjkstart鋼 & 4,501 & 400 & 185 & \\
\hline 151 & 日＼cjkstart曹＼cjkstart製 & 4,418 & 416 & -48 & \\
\hline 152 & 三 機 工 業 & 4,407 & 200 & 81 & \\
\hline 153 & 富士精 密工業 & 4,380 & 667 & 255 & \\
\hline 154 & 新 潟 鉄 工 所 & 4,379 & 600 & 231 & \\
\hline 155 & 尼力崎製 鋼 所 & 4,361 & 960 & $-1,205$ & \\
\hline 156 & 中 央 緎 維 & 4,320 & 500 & 82 & \\
\hline 157 & 日 本 精 工 & 4,270 & 400 & 384 & \\
\hline 158 & 日 本 特 殊 鋼 & 4,258 & 600 & 164 & \\
\hline 159 & 日 本繊 維 工業 & 4,245 & 1,000 & 113 & \\
\hline 160 & 神 崎 製 紙 & 4,224 & 250 & 236 & \\
\hline 161 & 大同製 & 4,150 & 840 & 210 & \\
\hline 162 & 中 央 毛 & 4,147 & 570 & 228 & \\
\hline
\end{tabular}


第18巻 第 1 号

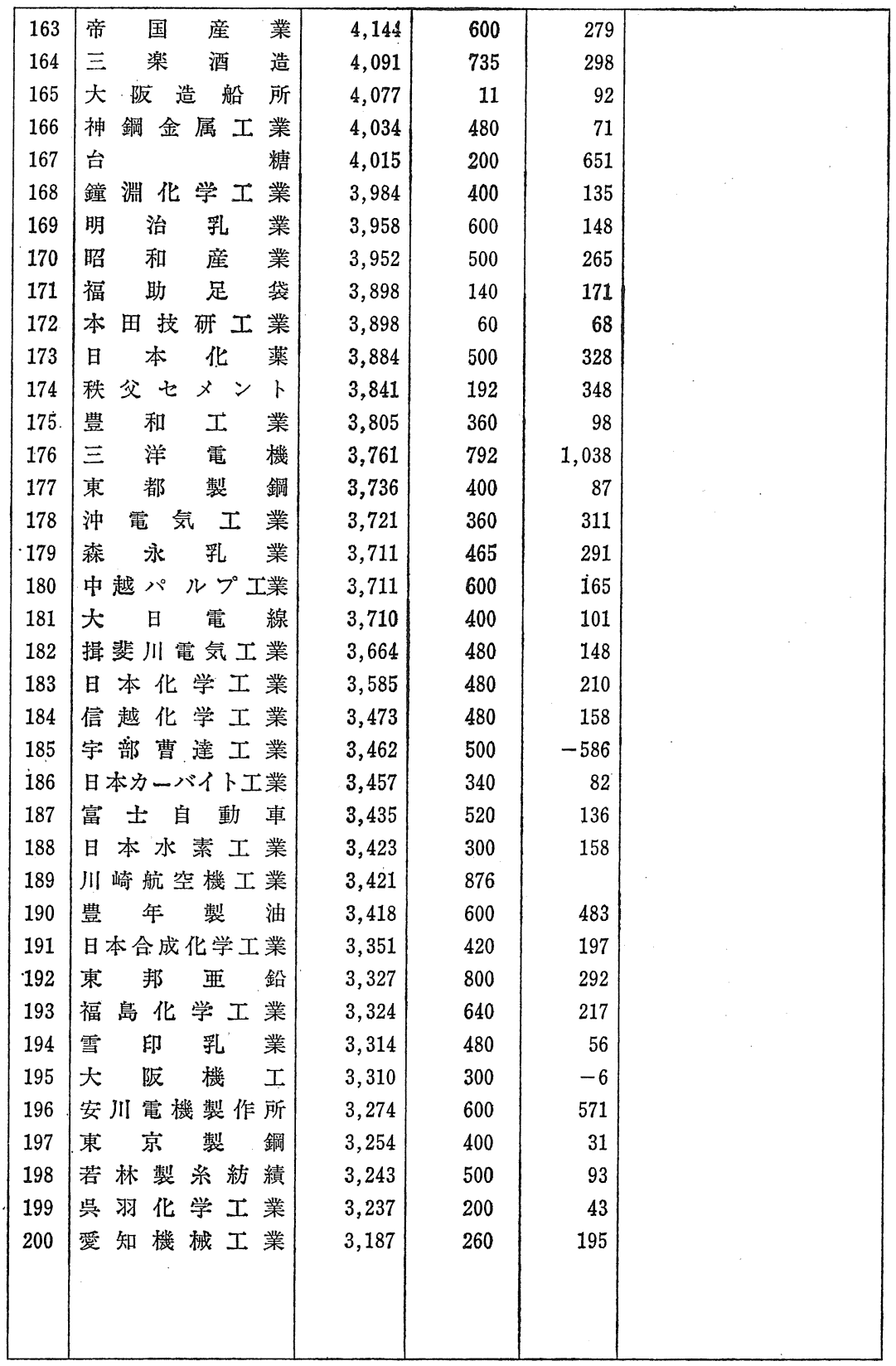




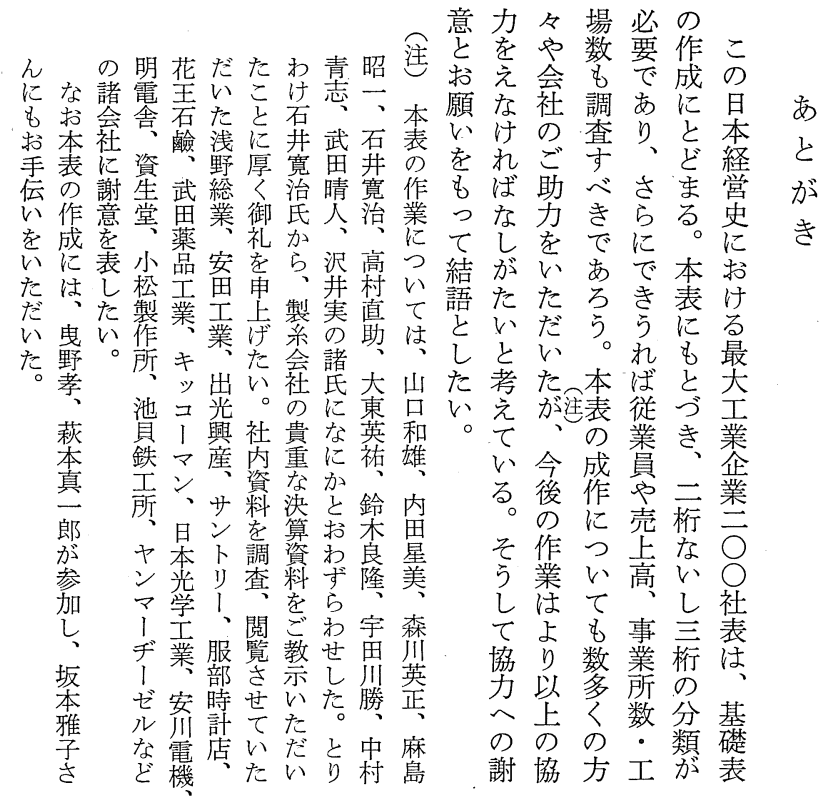


strictly speaking diversification to 'related business' according to R. P. Rumelt, was the result of amalgamations rather than internal growth. Furthermore, it was around this time that the post of 'General Manager' emerged, bringing an 'Age of General Managers' to the British insurance business. Thirdly, traditional London based offices (e.g. London Assurance) and specialist life offices (e.g. Scottish Widows' Fund) continued to lose their shares in the insurance market. To the contrary, some active non-London insurance offices, which had a comparatively short history, gradually became of increasing importance.

\title{
THE LISTS OF THE 200 LARGEST INDUSTRIAL ENTERPRISES IN JAPAN
}

\author{
Tsunehiko Yui \\ Mark Fruin
}

The lists presented here are the data showing the financial records of the 200 largest enterprises in the development of Japanese business. These lists rank large industrial enterprises in the order of the size of the firm and also provide information on the amount of assets, paid-up capital and revenue of each of the enterprises.

As the main purpose of this survey is a comparative study among industrialized countries, the lists are devised to the extent possible to be adaptable to international standards. (1) The enterprises listed are the 200 largest industrial enterprises, in accordance with the list of the United States and United Kingdom. (2) The authors researched the year 1918, 1930 and 1954. Although the data for the U. S. and the U. K. includes a list for 1949, marking the beginning of the post World War II period, the authors analyzing Japanese enterprises listed the 200 industrial firms of 1954 instead of 1949, because in 1949 Japanese large enterprises had not yet 
recovered from the war damage. (3) The standard for ranking enterprises in the lists is the sum of assets in real terms, mainly because most of the Japanese companies before World War II had not published their sales figures. (4) The definition and classification of "industry" is based on the SIC (Standard Classification of Industry) in the U. S. 